\title{
Hyaluronic acid-nimesulide conjugates as anticancer drugs against CD44-overexpressing HT-29 colorectal cancer in vitro and in vivo
}

This article was published in the following Dove Press journal:

International Journal of Nanomedicine

27 March 2017

Number of times this article has been viewed

\author{
You-Sin Jian' \\ Ching-Wen Chen' \\ Chih-An Lin² \\ Hsiu-Ping Yu' \\ Hua-Yang Lin ${ }^{3}$ \\ Ming-Yuan Liao' \\ Shu-Huan $\mathrm{Wu}^{\prime}$ \\ Yan-Fu Lin' \\ Ping-Shan Lai ${ }^{1,2,4,5}$ \\ 'Department of Chemistry, ${ }^{2} \mathrm{PhD}$ \\ Program in Tissue Engineering and \\ Regenerative Medicine, National \\ Chung Hsing University, Taichung, \\ ${ }^{3}$ Preclinical Development Research \\ Department, Holy Stone Healthcare \\ Co., Ltd., Taipei, ${ }^{4}$ Research Center \\ for Sustainable Energy and \\ Nanotechnology, ${ }^{5}$ Rong Hsing \\ Research Center for Translational \\ Medicine, National Chung Hsing \\ University, Taichung, Taiwan
}

\begin{abstract}
Carrier-mediated drug delivery systems are promising therapeutics for targeted delivery and improved efficacy and safety of potent cytotoxic drugs. Nimesulide is a multifactorial cyclooxygenase 2 nonsteroidal anti-inflammatory drug with analgesic, antipyretic and potent anticancer properties; however, the low solubility of nimesulide limits its applications. Drugs conjugated with hyaluronic acid (HA) are innovative carrier-mediated drug delivery systems characterized by CD44-mediated endocytosis of HA and intracellular drug release. In this study, hydrophobic nimesulide was conjugated to HA of two different molecular weights (360 kDa as HA with high molecular weight [HAH] and $43 \mathrm{kDa}$ as $\mathrm{HA}$ with low molecular weight [HAL]) to improve its tumor-targeting ability and hydrophilicity. Our results showed that hydrogenated nimesulide ( $N$-[4-amino-2-phenoxyphenyl]methanesulfonamide) was successfully conjugated with both HA types by carbodiimide coupling and the degree of substitution of nimesulide was $1 \%$, which was characterized by ${ }^{1} \mathrm{H}$ nuclear magnetic resonance $400 \mathrm{MHz}$ and total correlation spectroscopy. Both Alexa Fluor ${ }^{\circledR} 647$ labeled HAH and HAL could selectively accumulate in CD44-overexpressing HT-29 colorectal tumor area in vivo, as observed by in vivo imaging system. In the in vitro cytotoxic test, HA-nimesulide conjugate displayed $>46 \%$ cell killing ability at a nimesulide concentration of $400 \mu \mathrm{M}$ in HT-29 cells, whereas exiguous cytotoxic effects were observed on HCT-15 cells, indicating that HA-nimesulide causes cell death in CD44-overexpressing HT-29 cells. Regarding in vivo antitumor study, both HAL-nimesulide and HAH-nimesulide caused rapid tumor shrinkage within 3 days and successfully inhibited tumor growth, which reached $82.3 \%$ and $76.4 \%$ at day 24 through apoptotic mechanism in HT-29 xenografted mice, without noticeable morphologic differences in the liver or kidney, respectively. These results indicated that HA-nimesulide with improved selectivity through HA/CD44 receptor interactions has the potential to enhance the therapeutic efficacy and safety of nimesulide for cancer treatment.
\end{abstract}

Keywords: COX-2 inhibitor, nimesulide, hyaluronic acid, CD44, colorectal cancer

\section{Introduction}

Colorectal cancer (CRC) with insidious onset, low early diagnostic rate and poor longterm prognosis, is one of the most common malignancies in industrialized countries, and mortality from CRC is primarily attributable to metastatic cancer in the liver or lung. The current treatment for patients with CRC is primary surgical resection without or with chemotherapy using conventional chemotherapeutic agents such as 5-fluorouracil (5-FU), irinotecan and oxaliplatin. ${ }^{1-3}$ However, chemoresistance has been widely observed and recognized as a key reason for the failure of CRC chemotherapy., Therefore, developing new strategies for CRC treatment has recently attracted the attention of researchers.
Correspondence: Ping-Shan Lai; Yan-Fu Lin

Department of Chemistry, National Chung Hsing University, No 250, KuoKuang Road, Taichung 402, Taiwan Tel +886 4228404 I I ext 428 Fax +886 422862547 Email pslai@email.nchu.edu.tw; wylin@dragon.nchu.edu.tw 
CD44 is a multifunctional cell surface receptor that participates in many cellular processes, including growth, survival, differentiation and motility ${ }^{6-9}$ This receptor also has an important role in cancer cell migration and matrix adhesion in the cellular microenvironment, thereby enhancing cellular aggregation and tumor growth. ${ }^{10,11}$ Recently, prominent expression of CD44 has been considered as a hallmark of highly tumorigenic CRC cells ${ }^{12}$ and as a component of an intestinal cancer stem cell gene signature that predicts disease relapse in CRC patients. ${ }^{13}$ This signature is specifically associated with CRC cells endowed with high tumor-initiating potential as well as long-term self-renewal capacity. Hence, CD44 represents a potential therapeutic target for the treatment of CRC. ${ }^{14-16}$

Hyaluronic acid (HA), which is composed of disaccharide repeats of D-glucuronic acid and $N$-acetyl-D-glucosamine, is a linear polysaccharide that binds specifically to cell surface receptors, such as CD44, RHAMM and ICAM-1, to activate a wide range of intracellular signals and regulate various cellular processes, including morphogenesis, wound healing, inflammation and pathologic conditions. ${ }^{17-19}$ In addition, with its excellent hydrophilicity, high biocompatibility, nontoxic and nonirritant properties, HA is a favorable natural material for biomedical applications, such as cosmetics, ${ }^{20}$ cell therapy, ${ }^{21}$ tissue engineering ${ }^{22}$ and drug delivery. ${ }^{23-25}$ One of the advantages of using HA conjugation is that it improves the water solubility of hydrophobic drugs such as paclitaxel and curcumin ${ }^{26-28}$ and provides the targeting ability for drug delivery system. HA of different molecular weights has various roles in the body. HA of high molar mass $(1,000 \mathrm{kDa})$ has important physiological roles in living organisms, including the maintenance of the viscoelasticity of liquid connective tissues and proteoglycan organization in the extracellular matrix. HA of low molar mass is hypothesized to induce receptor-mediated intracellular signaling, thereby acting as an endogenous signal for T-cell activation and inducing the processes of inflammation and angiogenesis. ${ }^{29-31}$

Inflammation increases the development of precancerous lesions at various anatomic sites. For example, a 13.6\% increased risk of prostate cancer is noted for patients who previously suffered from prostatitis ${ }^{32}$ and a $25 \%$ increased CRC risk due to ulcerative colitis has also been reported. ${ }^{33}$ Nimesulide, a selective cyclooxygenase 2 inhibitor, is a drug with anti-inflammatory, analgesic, antipyretic properties ${ }^{34,35}$ and chemopreventive activity against urinary bladder, colon, liver and breast carcinogenesis. ${ }^{36-38}$ It is reported that nimesulide induces cell apoptosis and inhibits tumor growth in various types of cancer in both in vitro and in vivo studies; ${ }^{39-43}$ however, poor water solubility of nimesulide limits its biomedical applications. ${ }^{44,45}$ General dosage forms of nimesulide are tablets or capsules for anti-inflammatory treatments. ${ }^{46}$ The injectable nimesulide formulation with ethanolamine, L-cysteine, ethylenediaminetetraacetic acid (EDTA) and lactic acid, was recently developed. ${ }^{47}$ New nimesulide formulation for intravenous injection has been scarcely reported. In this study, nimesulide was conjugated to HA to improve its water solubility and tumor selectivity, and the antitumor efficacy of HA-nimesulide conjugates with two different molecular weights was evaluated in vitro and in vivo.

\section{Materials and methods Materials}

HA (HA with high molecular weight [HAH] $360 \mathrm{kDa}$ and HA with low molecular weight [HAL] $43 \mathrm{kDa}$; Freda Biopharm) was obtained from HolyStone (Taipei, Taiwan). Nimesulide, 1-ethyl-3-(3-dimethylaminopropyl)-carbodiimide (EDC) hydrochloride, $N$-hydroxysuccinimide (NHS), ethyl (hydroxyimino)cyanoacetate (Oxyma), fluorescein isothiocyanate (FITC) isomer I, adipic acid dihydrazide $(\mathrm{ADH})$, penicillin-streptomycin-neomycin (PSN) solution and $10 \%$ formalin were purchased from Sigma-Aldrich (St Louis, MO, USA). Dimethyl sulfoxide (DMSO), dimethylformamide and $\mathrm{Pd} / \mathrm{C}(5 \%)$ were obtained from ACROS (New Jersey, USA). For cell culture studies, Dulbecco's Modified Eagle's Medium (DMEM), DMEM:Nutrient Mixture F-12 (DMEM/F12), 3-(4,5-dimethylthiazol-2-yl)-2,5-diphenyltetrazolium bromide (MTT), fetal bovine serum (FBS) and $0.25 \%$ trypsin-EDTA were purchased from Thermo Fisher Scientific (Waltham, MA, USA). Alexa Fluor ${ }^{\circledR} 647$ cadaverine was purchased from Thermo Fisher Scientific.

\section{Synthesis of N-(4-amino-2- phenoxyphenyl)methanesulfonamide $\left(\mathrm{NiNH}_{2}\right)$}

To synthesize $\mathrm{NiNH}_{2}$ for further HA conjugation, a solution of $0.5 \mathrm{~g}$ of nimesulide $\left(\mathrm{NiNO}_{2}\right)$ in $20 \mathrm{~mL}$ ethyl acetate was hydrogenated at room temperature and atmospheric pressure in the presence of $0.2 \mathrm{~g} \mathrm{Pd} / \mathrm{C}(5 \%)$ for $24 \mathrm{~h}$ (Figure 1). The reaction was monitored by thin layer chromatography on silica gel plates and visualized with ultraviolet light. After the completion of the reaction, the catalyst was filtered, and the filtrate was precipitated in excess ethyl ether and evaporated in vacuo to provide $\mathrm{NiNH}_{2}$ powder. The product was verified by ${ }^{1} \mathrm{H}$ nuclear magnetic resonance (NMR) 400 $\mathrm{MHz}$ analysis using the following parameters: ${ }^{1} \mathrm{H}$ NMR (400 MHz, DMSO-d6; $\delta \mathrm{H} 2.85$ [s, 3H, $\mathrm{CH}_{3}$ ], 5.24 [deuterium 
A $\mathrm{O}_{2} \mathrm{~N}$

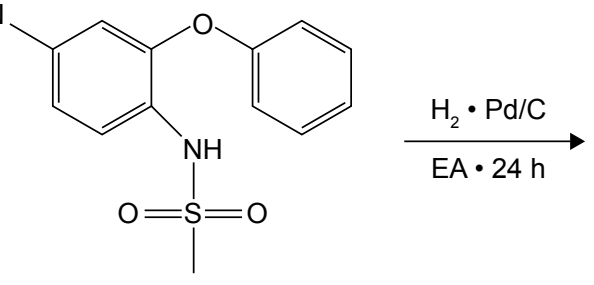

B

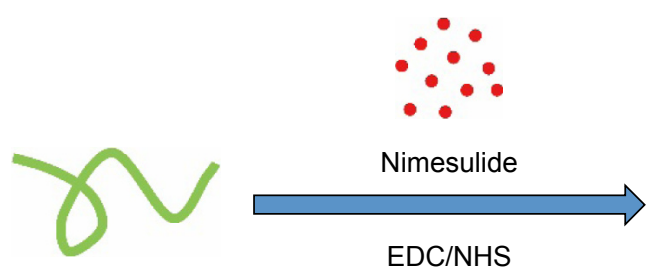

Hyaluronic acid<smiles>CS(=O)(=O)Nc1ccc(N)cc1Oc1ccccc1</smiles>

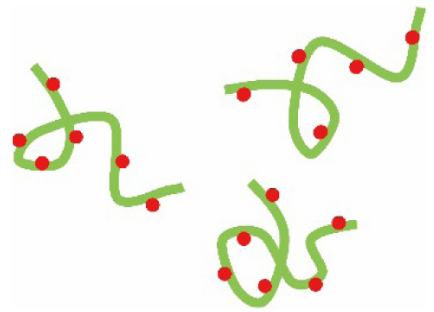

HA-nimesulide

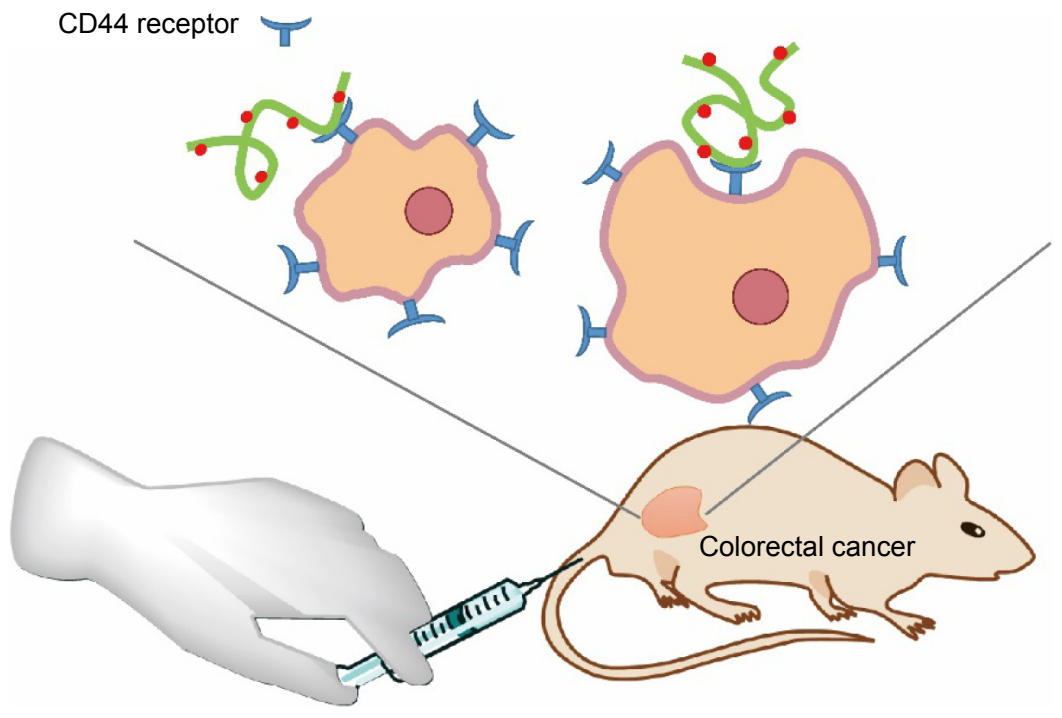

Figure I Schematic illustration of the synthesis of (A) $\mathrm{NiNH}_{2}$ and (B) HA-nimesulide conjugates.

Abbreviations: EA, ethyl acetate; EDC, I-ethyl-3-(3-dimethylaminopropyl)-carbodiimide; HA, hyaluronic acid; h, hours; NHS, N-hydroxysuccinimide; $\mathrm{NiNH}_{2}, \mathrm{~N}$-(4-amino2-phenoxyphenyl)methanesulfonamide.

exchangeable s, $2 \mathrm{H}, \mathrm{NH}_{2}$ ], 6.01 [d, $\left.1 \mathrm{H}, \mathrm{J}=3 \mathrm{~Hz}\right], 6.2-6.3$ [dd, $1 \mathrm{H}, \mathrm{J}=3 \mathrm{~Hz}, 6 \mathrm{~Hz}], 6.9-7.2$ [m, 4H], 7.3-7.5 [m, 2H], 8.73 [deuterium exchangeable s, $1 \mathrm{H}, \mathrm{NH}])_{4}^{48,49}$

\section{Synthesis of HA-conjugated nimesulide}

For HAH-nimesulide synthesis, $1 \mathrm{~g}$ of HAH was first dissolved in $500.0 \mathrm{~mL}$ of water and reacted with $20.0 \mathrm{~mL}$ of EDC/ NHS water solution (502 $\mathrm{mg}$ of EDC and $302 \mathrm{mg}$ of NHS) for 5 minutes. Then, $72 \mathrm{mg}$ of $\mathrm{NiNH}_{2}$ powder dissolved in $1 \mathrm{~mL}$ DMSO was added to activated $\mathrm{HAH}$ solution and made to react for $12 \mathrm{~h}$ at room temperature. The resulting solution was dialyzed using a 3500 molecular weight cutoff (MWCO) dialysis bag against a large excess of $0.3 \mathrm{M} \mathrm{NaCl}$ solution and water for 4 days. For HAL-nimesulide synthesis, $700 \mathrm{mg}$ of HAL was first dissolved in a solution mixture containing $140.0 \mathrm{~mL}$ of water and $70.0 \mathrm{~mL}$ of DMSO, and made to react with $14.0 \mathrm{~mL}$ of EDC/NHS solution (351 $\mathrm{mg}$ of EDC and $211 \mathrm{mg}$ of NHS) for 5 minutes. Then, $100.8 \mathrm{mg}$ of $\mathrm{NiNH}_{2}$ dissolved in $7.0 \mathrm{~mL}$ of DMSO was added to the activated HAL solution. After stirring for $12 \mathrm{~h}$, the resulting solution was dialyzed using an MWCO 3500 dialysis bag for 5 days, lyophilized and then stored at $4^{\circ} \mathrm{C}$ for further studies. The structure of the sample and the degree of substitution (DS) of HA-nimesulide, defined as the number of nimesulide molecules per HA molecule, were estimated by ${ }^{1} \mathrm{H}$ NMR $400 \mathrm{MHz} .{ }^{50,51}$

\section{Synthesis of fluorescent dye-labeled HA}

FITC-labeled HAH (HAH-ADH-FITC) was prepared by chemical conjugation of FITC with the amine group of HAADH through thiourea formation. First, $50 \mathrm{mg}$ of HAH was 
dissolved in $12.5 \mathrm{~mL}$ of water and $114.8 \mathrm{mg}$ of $\mathrm{ADH}$ was added to HAH solution. Then, the $\mathrm{pH}$ of the reaction mixture was adjusted to 4.75 by addition of $0.1 \mathrm{~N} \mathrm{HCl}_{(\mathrm{aq})}$, and $25.1 \mathrm{mg}$ of EDC was added to this mixture for activation of carboxyl group of HA. After 15 minutes, the reaction was quenched by addition of $0.1 \mathrm{~N} \mathrm{NaOH}_{(\mathrm{aq})}$ and the resulting solution was then transferred to pretreated dialysis tubing (MWCO 3500) and dialyzed exhaustively against $0.3 \mathrm{M} \mathrm{NaCl}_{(\mathrm{aq})}$ and water for 4 days. The resulting solution was lyophilized and stored at $4{ }^{\circ} \mathrm{C}$. The DS of ADH in HAH-ADH was measured by ${ }^{1} \mathrm{H}$ NMR $400 \mathrm{MHz}{ }^{52,53}$ For HAH-ADH-FITC synthesis, HAH$\mathrm{ADH}$ (88 mg) was first dissolved in $35 \mathrm{~mL}$ water, mixed with FITC solution (9.5 mg of FITC dissolved in $10 \mathrm{~mL}$ DMSO) for $48 \mathrm{~h}$ at room temperature, and then the mixture was dialyzed against $0.3 \mathrm{M} \mathrm{NaCl}_{(\mathrm{aq})}$ and pure water alternately using an MWCO 12,000-14,000 dialysis bag. The resulting solution was lyophilized, analyzed by fluorescence spectrometer (FP-6300; Jasco, Japan) and then stored at $4^{\circ} \mathrm{C}$ before use.

NIR dye (Alexa Fluor 647 cadaverine)-labeled HAH (HAH-NIR dye) and HAL-NIR dye were synthesized by activation of carboxyl group of HA. First, $40 \mathrm{mg}$ of HAH or HAL and $11 \mathrm{mg}$ of Oxyma were dissolved in $4 \mathrm{~mL}$ water. Then, $2 \mathrm{~mL}$ dimethylformamide was added to the HA solution. Second, $32 \mu \mathrm{L}$ of DIC was added into the mixture solution. After stirring for 5 minutes, $0.2 \mathrm{mg}$ of NIR dye dissolved in $100 \mu \mathrm{L}$ water was added to the activated HA solution and made to react for $24 \mathrm{~h}$ at room temperature. Then, the solution was added to $32 \mu \mathrm{L}$ of DIC and made to react for $24 \mathrm{~h}$. The resulting solution was dialyzed using an MWCO 3500 dialysis bag for 5 days, lyophilized, analyzed by fluorescence spectrometer (FP-6300; Jasco) and then stored at $4^{\circ} \mathrm{C}$ before use.

\section{GPC analysis of HA-nimesulide conjugates}

The molecular weight distribution of HA and HAH-nimesulide aqueous solution was assessed by the GPC system consisting of a Waters 600 pump controller (Waters, Milford, MA, USA), an injection valve with a $200 \mu \mathrm{L}$ sample loop, ultrahydrogel 2,000 and 250 columns $7.8 \times 300 \mathrm{~mm}$ (Waters), a 2,414 refractive index detector (Waters) and a photo diode array (set to $254 \mathrm{~nm}$, the $\sim \lambda_{\text {max }}$ of nimesulide; Waters), using the mobile phase $0.02 \mathrm{M} \mathrm{NH}_{4} \mathrm{H}_{2} \mathrm{PO}_{4(\mathrm{aq})}$ and $0.3 \mathrm{M} \mathrm{NaNO}_{3(\mathrm{aq})}$ at $40^{\circ} \mathrm{C}$ at a flow rate of $0.7 \mathrm{~mL} / \mathrm{min}$.

\section{Cell culture and flow cytometry analysis}

HT-29 and HCT-15 human CRC cells were purchased from American Type Culture Collection. HT-29 or HCT-15 human CRC cells were grown in T75 flasks using DMEM or
DEMM/F12 culture medium supplemented with $10 \%$ (v/v) FBS and 1\% PSN solution, respectively. The cells were maintained in a humidified incubator at $37^{\circ} \mathrm{C}$ in $5 \% \mathrm{CO}_{2}$ and subcultured two to three times per week using $0.25 \%$ trypsin. To evaluate CD44 receptor expression in HT-29 or HCT-15, the cells were washed once with phosphate-buffered saline (PBS) and then harvested with $0.25 \%$ trypsin-EDTA. The detached cells were washed with PBS containing 1\% FBS and 1\% penicillin/streptomycin (wash buffer), and resuspended in wash buffer $\left(1 \times 10^{6}\right.$ cells $\left./ \mathrm{mL}\right)$. Anti-CD44 antibodies conjugated with FITC (CD44-FITC; eBioscience) were added at a dilution of 1:200 and incubated in the dark on ice for 30 minutes. The labeled cells were washed in PBS, fixed in PBS containing $4 \%$ paraformaldehyde and analyzed on an Accuri ${ }^{\mathrm{TM}}$ C6 (BD Accuri cytometers; BD Biosciences, Ann Arbor, MI, USA). The amount of cellular uptake of HAH-ADH-FITC by HT-29 and HCT-15 cells was assessed by flow cytometry. Briefly, HT-29 or HCT-15 cells $\left(1 \times 10^{6}\right.$ cells/well $)$ were seeded into six-well plate for $24 \mathrm{~h}$. HAH-ADH-FITC (FITC: $1 \mu \mathrm{M}$; HAdye: $1 \mathrm{mg} / \mathrm{mL}$ ) was added to the cells for various incubation time periods, respectively. The cells were washed once with PBS and then harvested with $0.25 \%$ trypsin-EDTA. The detached cells were resuspended in culture medium. The cells were then analyzed by Accuri $\mathrm{C}^{6}$ (BD Accuri cytometers) using FL1 (533/30 nm). For apoptotic analysis, cells treated with $\mathrm{H}_{2} \mathrm{O}_{2}$ at $10 \mathrm{mM}$ or $\mathrm{HAL}$-nimesulide at $200 \mu \mathrm{M}$ nimesulide concentration for $48 \mathrm{~h}$ were harvested by trypsinization, washed with PBS and resuspended in binding buffer $(200 \mu \mathrm{L})$ containing Annexin V-FITC $(20 \mu \mathrm{g} / \mathrm{mL})$ and propidium iodide $(20 \mu \mathrm{g} / \mathrm{mL})$ for 30 minutes at room temperature. The cells were then analyzed by Accuri C6 (BD Accuri cytometers) using FL1 $(533 / 30 \mathrm{~nm})$ and FL3 (610/20 nm).

\section{Cytotoxicity assay}

To evaluate the cytotoxicity of free nimesulide, modified nimesulide $\mathrm{NiNH}_{2}, \mathrm{HAH}$-nimesulide and $\mathrm{HAL}$-nimesulide conjugates on HT-29 and HCT-15 cells, the cells were seeded in a 96-well plate at $1 \times 10^{4}$ cells/well with the medium supplemented with 10\% FBS and 1\% PSN solution and cultured for $24 \mathrm{~h}$ prior to experimentation. Subsequently, the cells were treated with a medium mixed with twofold serial dilutions of nimesulide or an equivalent nimesulide concentration ranging from 400 to $3.125 \mu \mathrm{M}$. HAH- or HAL-treated cells were used as a control group. After $48 \mathrm{~h}$, the cells were washed three times with PBS and incubated in fresh medium containing MTT in the dark for an additional $3 \mathrm{~h}$. After removal of the medium, $100 \mu \mathrm{L}$ of DMSO was added into each well with continuous shaking for 30 minutes. The results were read using a scanning multiwell plate reader 
at $570 \mathrm{~nm}\left(\right.$ SpectraMax $^{\circledR}$ M2e; Molecular Devices LLC, Sunnyvale, CA, USA).

\section{In vitro and in vivo fluorescence imaging of HA-dye}

To evaluate the cellular uptake and HAH-ADH-FITC binding affinity in different cell lines, HT-29 or HCT-15 cells $\left(5 \times 10^{4}\right.$ cells/well) were seeded into glass coverslips for $24 \mathrm{~h}$. CD44-FITC or HAH-ADH-FITC (FITC: $1 \mu \mathrm{M}$; HA-dye: $1 \mathrm{mg} / \mathrm{mL}$ ) was added to the cells for various incubation time periods, respectively. CD44-FITC-treated groups served as the positive control. Hoechst 33342 solution was added to the cells and incubated for 10 minutes. After staining, the cells were washed with $1 \times$ PBS three times, mounted onto glass slides, and the fluorescent signals were examined by confocal laser scanning microscopy at an excitation of $488 \mathrm{~nm}$ and emission of 500-600 nm (Leica-SP5; Leica Microsystems, Heidelberg GmbH, Germany).

Noninvasive in vivo imaging system (IVIS) experiments were approved by the Institutional Animal Care and Use Committee (IACUC) of National Chung Hsing University, Taiwan, ROC (IACUC Permit No 104-020) based on the Guide for the Care and Use of Laboratory Animals. ${ }^{54}$ The high-level CD44 expression cell line HT-29 was used to establish a tumor animal model. Briefly, female athymic nu/nu (nude) mice (aged 5-6 weeks, BioLASCO, Taiwan, ROC) were sterilely and subcutaneously administered $2 \times 10^{7}$ HT- 29 cells in the right flank. HAH-NIR dye solution (HAH-NIR dye: $20 \mathrm{mg} / \mathrm{mL}, 200 \mathrm{mg} / \mathrm{kg}$ ) and HAL-NIR dye solution (HAL-NIR dye: $20 \mathrm{mg} / \mathrm{mL}, 200 \mathrm{mg} / \mathrm{kg}$ ) were intravenously injected through the tail vein when the tumors reached a volume of approximately $500-600 \mathrm{~mm}^{3}$. Images were recorded by the caliper IVIS system (excitation filter: $640 \mathrm{~nm}$, emission filter: $680 \mathrm{~nm}$, exposure time: $1 \mathrm{sec}, \mathrm{f} / \mathrm{stop}$ : 8 ) at 1, 4, 8, 24 and $48 \mathrm{~h}$ time points after injection. At the last time point, the mice were sacrificed by cervical dislocation. Fluorescence images of tumors, heart, liver, spleen, kidneys, brain and muscle were also analyzed by IVIS imaging system (IVIS ${ }^{\circledR}$ Spectrum CT; PerkinElmer Inc., Waltham, MA, USA). The fluorescence images were quantified by Living Image software (PerkinElmer Inc.).

\section{Antitumor effects of $\mathrm{HA}-$ nimesulide conjugates}

The in vivo antitumor experimental protocols were approved by IACUC of National Chung Hsing University, Taiwan, ROC (IACUC Permit No 104-020) based on the Guide for the Care and Use of Laboratory Animals. ${ }^{54}$ Female BALB/cAnN.Cg-Foxn1nu/CrlNarl nude mice (5-6 weeks old, $20 \pm 2 \mathrm{~g}$ ) were obtained from the National Laboratory Animal Center (Taiwan). All mice were maintained in an air-conditioned facility with an artificial light-dark cycle and were provided with standard food and filtered water. The mice were acclimated to this environment for at least 3 days prior to subcutaneous injection in the right hindquarter with $2 \times 10^{7}$ HT-29 cells suspended in medium. Tumor size and body weight were measured every 3 or 4 days for the duration of the experiment. Tumor volume was calculated as $1 / 2(4 \pi / 3)$ $(\mathrm{L} / 2)(\mathrm{W} / 2) \mathrm{H}$, where $\mathrm{L}$ is the length, $\mathrm{W}$ the width and $\mathrm{H}$ is the height of the tumor. Treatments were initiated when the tumors reached a volume of approximately $100 \mathrm{~mm}^{3}$ (day 0 ). Mice were randomized into six treatment groups ( $\mathrm{n}=4$ per group). The animals were injected with PBS (control group), nimesulide or $\mathrm{HA}$-nimesulide at $1.5 \mathrm{mg} / \mathrm{kg}$ equivalent nimesulide concentration for three times per week. Mice that received $50 \mathrm{mg} / \mathrm{kg} 5$-FU once per week through the lateral tail vein acted as the positive control group. ${ }^{55,56}$ Tumor size and body weight were recorded for each mouse every 3 or 4 days. The percentage of tumor growth inhibition (TGI \%) was calculated from the relative tumor volume at day 24 .

\section{Necropsy and terminal deoxynucleotidyl transferase dUTP nick end-labeling assay analysis of tumor sections}

Tumors were excised and weighed after the mice were sacrificed. Prior to immunohistochemical and hematoxylin and eosin staining, the tumor tissue was fixed in formalin and embedded in paraffin. Cell apoptosis was analyzed by a terminal deoxynucleotidyl transferase dUTP nick end-labeling (TUNEL) assay using a Click-i $\mathrm{T}^{\circledR}$ TUNEL Alexa Fluor Imaging Assay Kit (Thermo Fisher Scientific), and the experimental procedure was performed according to the manufacturer's instructions. Briefly, $2 \mu \mathrm{m}$ sections of tumors from mice in each treatment group were immersed in $0.25 \%$ Triton ${ }^{\circledR} \mathrm{X}-100$ PBS solution. After washing with PBS, the slices were stained with terminal deoxynucleotidyl transferase reaction cocktail for 90 minutes at $37^{\circ} \mathrm{C}$ and washed with PBS. Next, Click-iT reaction cocktail and Hoechst 33342 were used to stain the sections in the dark to label apoptotic cells and cellular DNA. After staining, Hoechst 33342 and Alexa Fluor ${ }^{\mathbb{B}} 488$ fluorescence was observed by Leica SP 5 confocal microscopy using an excitation of 405 or $488 \mathrm{~nm}$, respectively.

\section{Results and discussion} Characterization of $\mathrm{NiNH}_{2}$ and

\section{HA-nimesulide}

$\mathrm{NiNH}_{2}$ was synthesized through the hydrogenation of nimesulide. As shown in Figure 2, the peak of the amine group of 


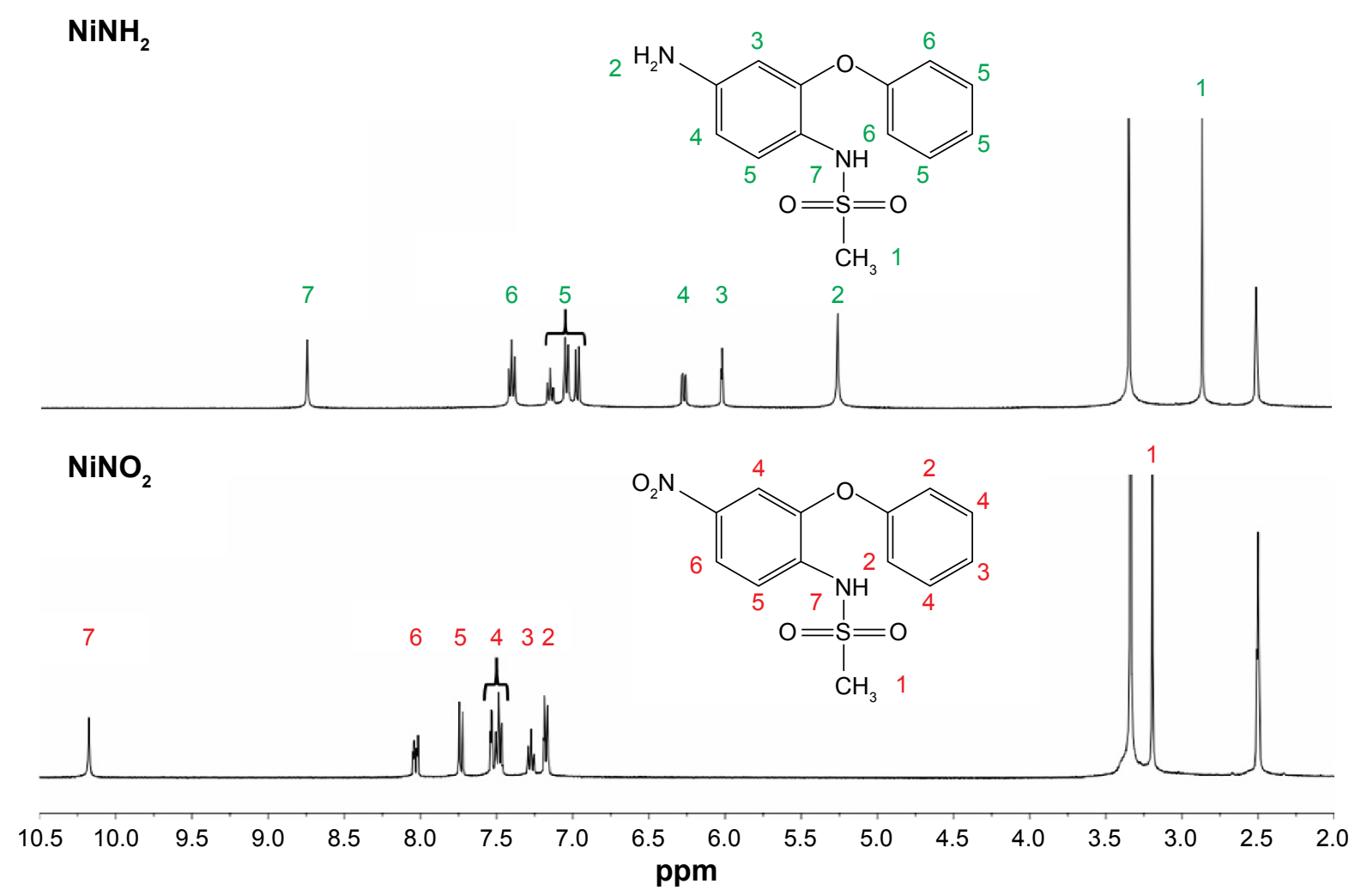

Figure 2 ' $\mathrm{H}$ NMR spectra of $\mathrm{NiNO}_{2}$ (nimesulide) and $\mathrm{NiNH}_{2}$.

Abbreviations: $\mathrm{NiNH}_{2}, \mathrm{~N}$-(4-amino-2-phenoxyphenyl)methanesulfonamide; $\mathrm{NMR}$, nuclear magnetic resonance.

$\mathrm{NiNH}_{2}$ was identified at $5.24 \mathrm{ppm}$, indicating the successful synthesis of $\mathrm{NiNH}_{2}$ that can further conjugate to HA. Figure 3 depicts the ${ }^{1} \mathrm{H}$ NMR spectra of HAH-nimesulide and HALnimesulide, wherein a strong acetyl $\left(-\mathrm{NHCOCH}_{3}\right)$ peak of $\mathrm{HA}$ is identified at $2.0 \mathrm{ppm}$ and peaks from the aromatic protons of nimesulide are in the range of 7.6-6.8 ppm. The DS of nimesulide in the synthesized HA-nimesulide conjugates, which is defined as the ratio of nimesulide per $100 \mathrm{HA}$ units, was calculated from the integration ratio of the characteristic peaks of HA at $2.0 \mathrm{ppm}$ and nimesulide at 7.6-6.8 ppm. The DS of HA-nimesulide, defined as the number of nimesulide molecules per HA molecule, was $1 \%$ as estimated by ${ }^{1} \mathrm{H}$ NMR $400 \mathrm{MHz}$. To further clarify the maintenance of nimesulide structure after the conjugation process, we used total correlation spectroscopy (TOCSY) to determine each signal of nimesulide after HA conjugation. As found in Figure 4, the TOCSY results clearly showed two spin systems. The first spin system contained protons at $7.05 \mathrm{ppm}\left(\mathrm{Ar}^{\prime}-2 \mathrm{H}, \mathrm{Ar}^{\prime}-6 \mathrm{H}\right), 7.18 \mathrm{ppm}\left(\mathrm{Ar}^{\prime}-4 \mathrm{H}\right)$ and $7.39 \mathrm{ppm}$ $\left(\mathrm{Ar}^{\prime}-3 \mathrm{H}, \mathrm{Ar}^{\prime}-5 \mathrm{H}\right)$, and the second spin system contained protons at $6.97 \mathrm{ppm}(\mathrm{Ar}-6 \mathrm{H})$ and $7.33 \mathrm{ppm}(\mathrm{Ar}-5 \mathrm{H})$, indicating that nimesulide was successfully conjugated to HA. These results are summarized in Table 1.

The molecular weight distribution of $\mathrm{HA}$ and HA-nimesulide was measured by GPC (Figure S1).
HAH-nimesulide displayed a similar retention time as original HA using the RI detector, indicating no apparent change in the molecular weight distribution of HA after nimesulide conjugation.

There are several strategies for hydrophobic drug-HA conjugation. For example, HA modified with ADH can successfully conjugate with hemisuccinate NHS activated ester of paclitaxel. ${ }^{52}$ 4-Bromobutyric-paclitaxel can be conjugated onto carbodiimide-activated HA by ester bond formation in an organic solvent. ${ }^{57}$ In this study, nimesulide was conjugated to HA using an EDC/NHS coupling agent in aqueous solution. After HA conjugation, the limitation of nimesulide, that is, its poor water solubility $(10.9 \mu \mathrm{g} / \mathrm{mL}),{ }^{45}$ significantly improved to $>600 \mu \mathrm{g} / \mathrm{mL}$. A low degree of substitution of nimesulide was observed in the reaction between hydrophobic nimesulide and hydrophilic HA in aqueous phase. This result may be due to the amine group of $\mathrm{NiNH}_{2}$ being a weak nucleophile in the coupling reaction.

\section{CD44 receptor expression and HA- ADH-FITC binding affinity in HT-29 and HCT-I 5 cells}

The level of CD44 expression in HT-29 and HCT-15 cells was first evaluated by flow cytometry. As shown in Figure $5 \mathrm{~A}$, the positive quantitative fluorescence levels of 
A $\mathrm{NiNH}_{2}$
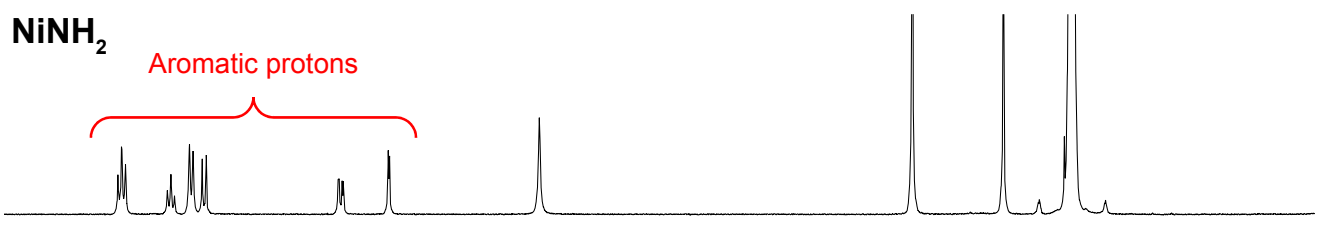

B HAL-nimesulide-1\%
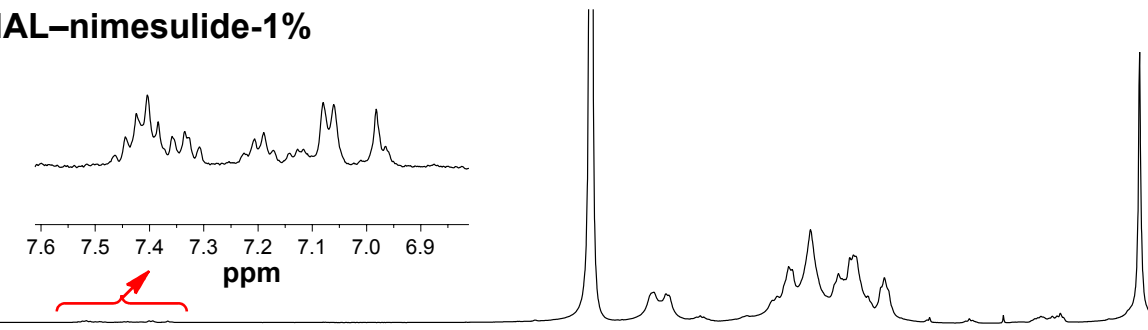

\section{HAH-nimesulide- $1 \%$}
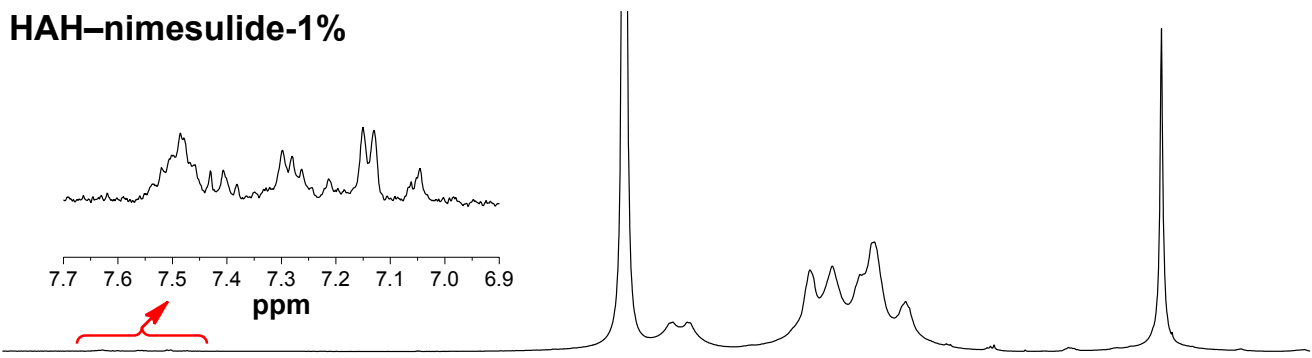

\section{D $\mathrm{HAH}$}

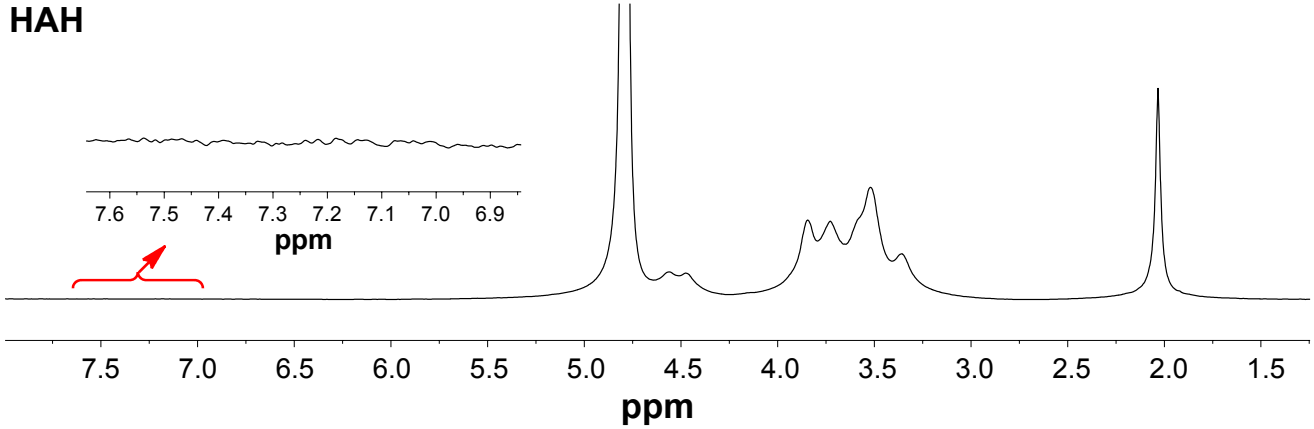

Figure 3 'H NMR spectra of (A) $\mathrm{NiNH}_{2}$, (B) HAL-nimesulide- I\%, (C) HAH-nimesulide- I\% and (D) free HAH.

Abbreviations: $\mathrm{NiNH}_{2}, \mathrm{~N}$-(4-amino-2-phenoxyphenyl)methanesulfonamide; $\mathrm{NMR}$, nuclear magnetic resonance; $\mathrm{HA}$, hyaluronic acid; $\mathrm{HAH}$, $\mathrm{HA}$ with high molecular weight; HAL, HA with low molecular weight.

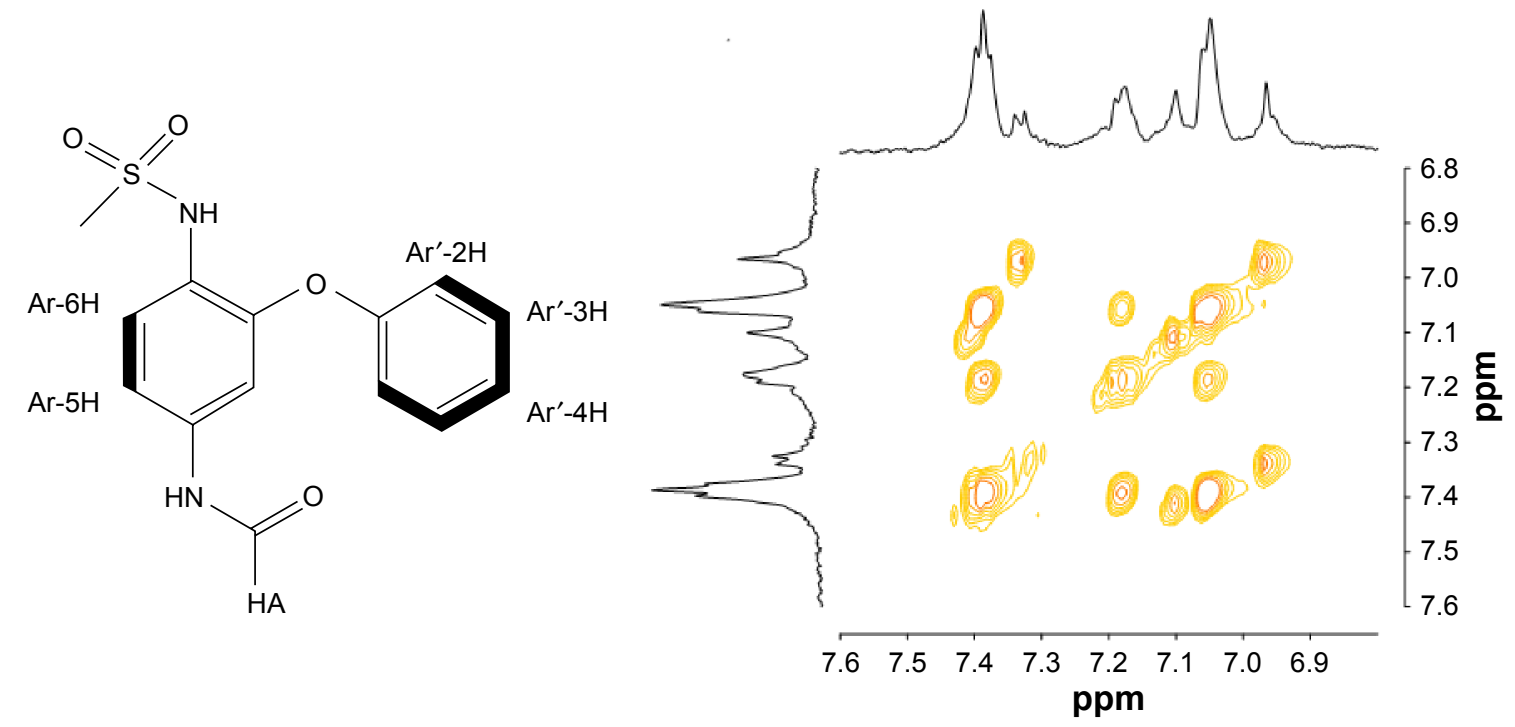

Figure 4 TOCSY (bold line) results for HA-nimesulide conjugate.

Abbreviations: HA, hyaluronic acid; TOCSY, total correlation spectroscopy. 
Table I 'H NMR spectroscopic data of aromatic ring of nimesulide in HA-nimesulide conjugate

\begin{tabular}{ll}
\hline Position & ppm \\
\hline Ar-3H & 7.10 \\
Ar-5H & 7.33 \\
Ar-6H & 6.97 \\
Ar'-2H, Ar'-6H & 7.05 \\
Ar'-3H, Ar'-5H & 7.39 \\
Ar'-4H & 7.18 \\
\hline
\end{tabular}

Abbreviations: HA, hyaluronic acid; NMR, nuclear magnetic resonance.

A

HT-29

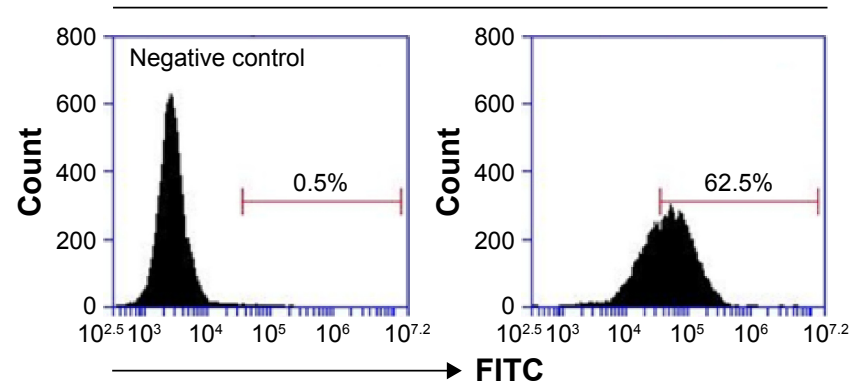

B
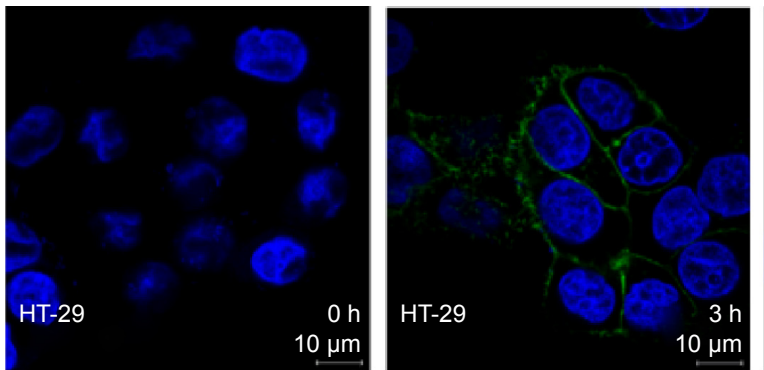

C
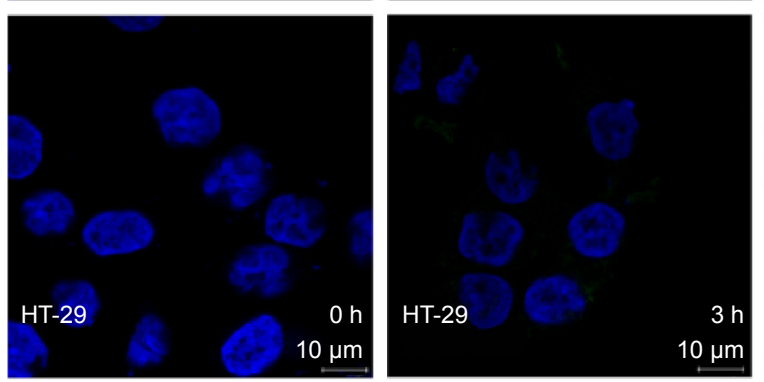

D
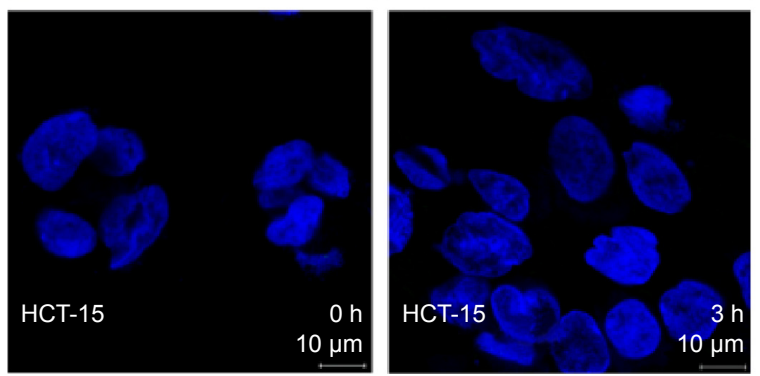

CD44 expression in HT-29 and HCT-15 cells were $62.5 \%$ and $18.4 \%$, respectively. Thus, HT-29 was considered to show a high level of CD44 receptor expression, whereas HCT-15 showed a low level of CD44 receptor expression. These expression phenomena were also determined by confocal microscopy. As shown in Figure 5B, FITC-conjugated CD44 antibody was clearly observed on the surface of HT-29 cells at $3 \mathrm{~h}$. However, no apparent fluorescence signal was detected in HCT-15 cells at the same time, consistent with
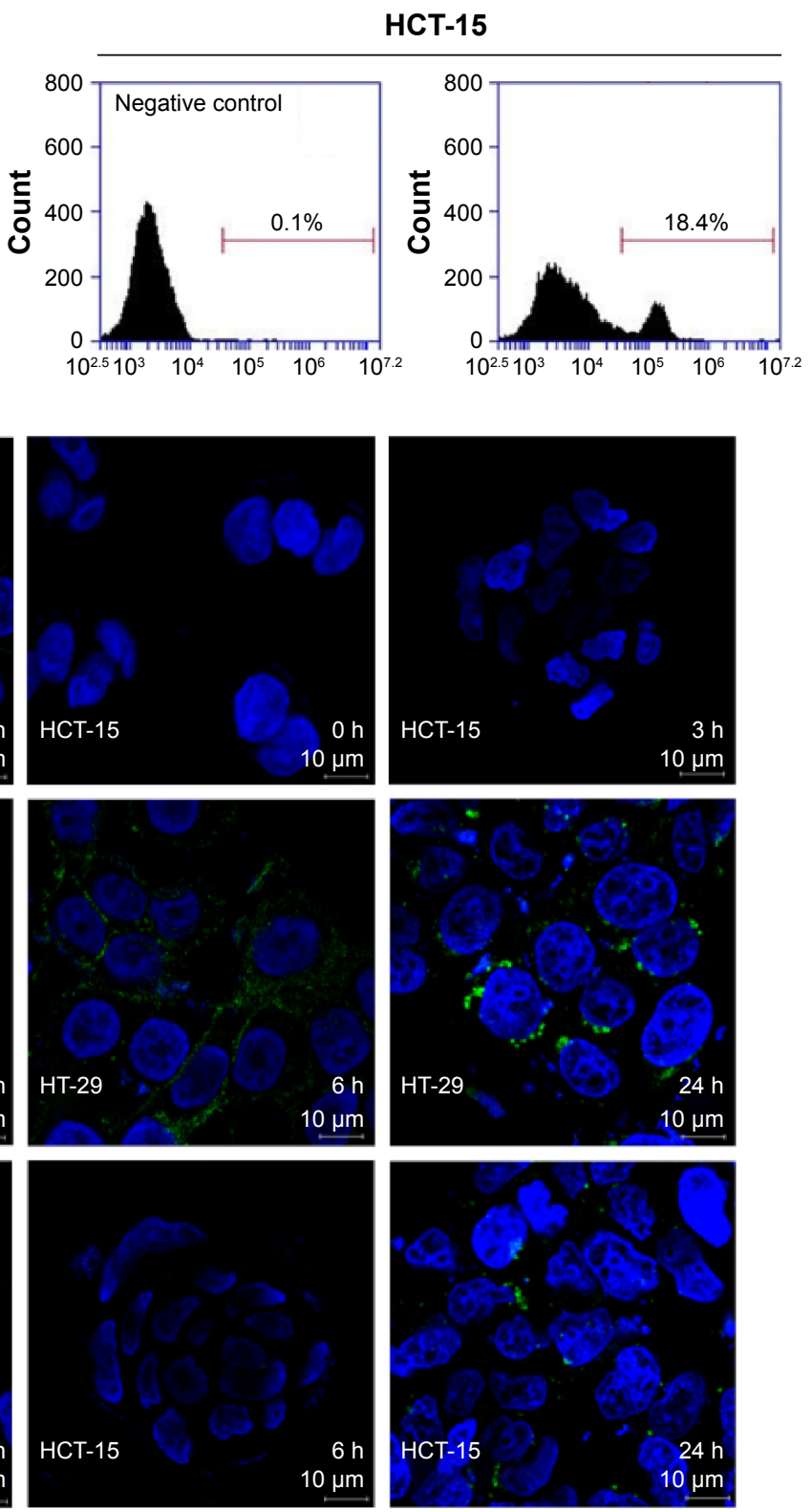

Figure 5 (A) Flow cytometry analysis of CD44 expression in HT-29 and HCT-15 cells; (B) immunocytochemistry of CD44 expression in HT-29 or HCT-I5 cells assessed by confocal microscopy at a concentration of I $\mu$ M CD44-FITC or I mg/mL HA-dye. Intracellular distribution of HAH-ADH-FITC at 3, 6 and 24 h posttreatment in (C) HT-29 and (D) HCT-I5 cells. Hoechst 33342 (shown in blue) is used for nuclei labeling. CD44-FITC or HAH-ADH-FITC is shown in green. Scale bar: $10 \mu$ m.

Abbreviations: ADH, adipic acid dihydrazide; FITC, fluorescein isothiocyanate; HA, hyaluronic acid; HAH, HA with high molecular weight. 
the CD44 expression results determined by flow cytometry (Figure 5A). The selectivity of FITC-labeled HA on HT-29 and HCT-15 cells was also evaluated using confocal microscopy. As shown in Figure 5C and D, the fluorescence signal of HAH-ADH-FITC was significantly observed in HT-29 cells at $6 \mathrm{~h}$, whereas only a few green dots were observed at $24 \mathrm{~h}$ in HAH-ADH-FITC-treated HCT-15 cells, indicating the selectivity of HAH-ADH-FITC for increased CD44 receptor expression in HT-29 cells and internalization by the ligand-receptor pathway. ${ }^{58}$ Cellular uptake of HAH-ADHFITC in HT-29 and HCT-15 cells were also analyzed by flow cytometry. The results showed that the $\mathrm{FITC}^{+}$cell expression in HT-29 and HCT-15 was $66.8 \%$ and $36.3 \%$ (Figure S2) after $3 \mathrm{~h}$ of incubation, respectively. At 6 and $24 \mathrm{~h}$ of incubation, the expression of FITC ${ }^{+}$cells in HT-29 and HCT-15 increased to $73.4 \%$ and $50.6 \%$, respectively. The mean fluorescence intensity in HAH-ADH-FITC-treated HT-29 groups was higher than that of HCT-15 groups, indicating more uptake of HAH-ADH-FITC in HT-29 cells.
Noninvasive IVIS imaging of HA-NIR dye in HT-29 subcutaneous colorectal tumorbearing mice

To evaluate tumor accumulation of NIR dye-labeled HA with different molecular weights in vivo, HAH-NIR dye or HALNIR dye was intravenously injected into mice and the fluorescence signals of NIR dye were monitored by IVIS. Obviously, mice that received HAH-NIR or HAL-NIR revealed apparent fluorescence signals from 1 to $48 \mathrm{~h}$ postinjection, whereas quick elimination of free NIR dye was observed (Figure 6A). This result indicates that HAH-NIR or HAL-NIR swiftly distributed to the whole body during circulation after injection. To further investigate tumor accumulation of HAH-NIR or HAL-NIR, the fluorescence intensity of tumor area observed in Figure 6A was analyzed and the quantitative result was shown in Figure 6B. Significantly increased fluorescence intensity of HAH-NIR in the tumor area was detected as time increased. The fluorescence intensity showed threefold increase at $48 \mathrm{~h}$ postinjection, compared to that at $1 \mathrm{~h}$

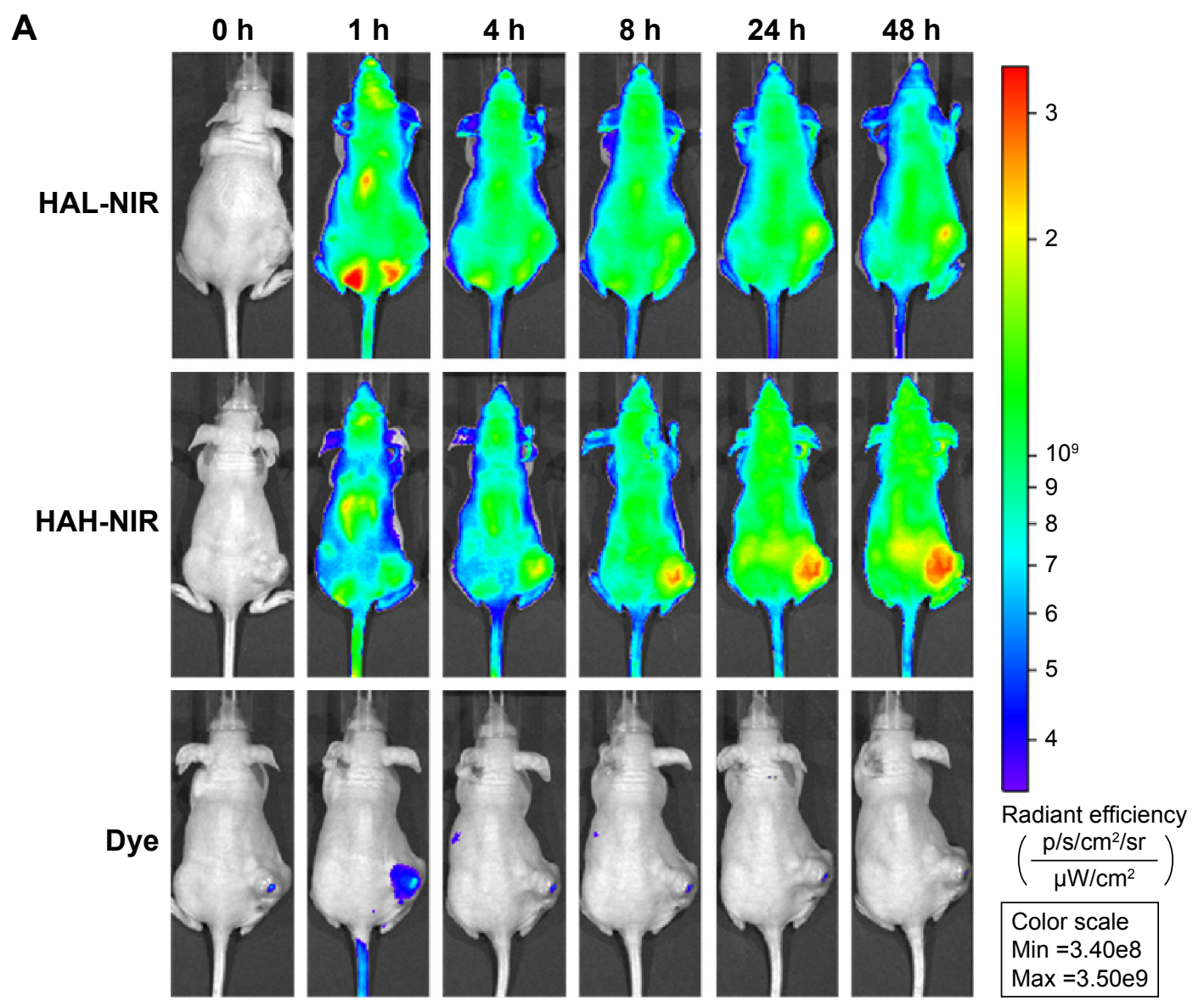

Figure 6 (Continued) 
B

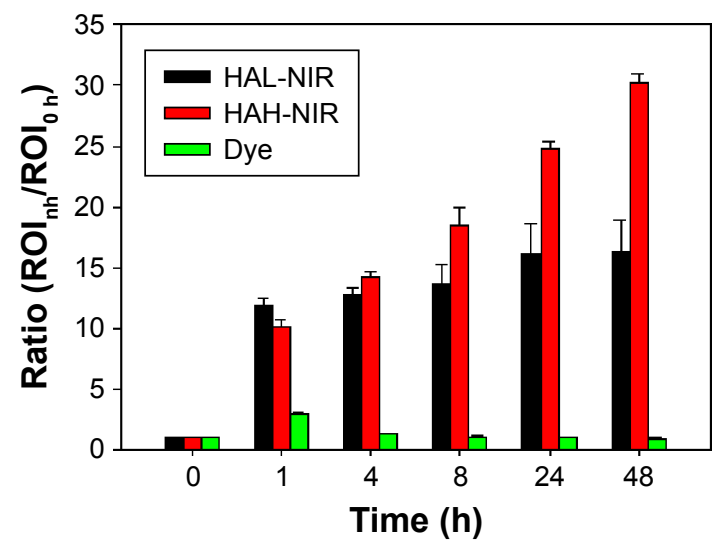

D

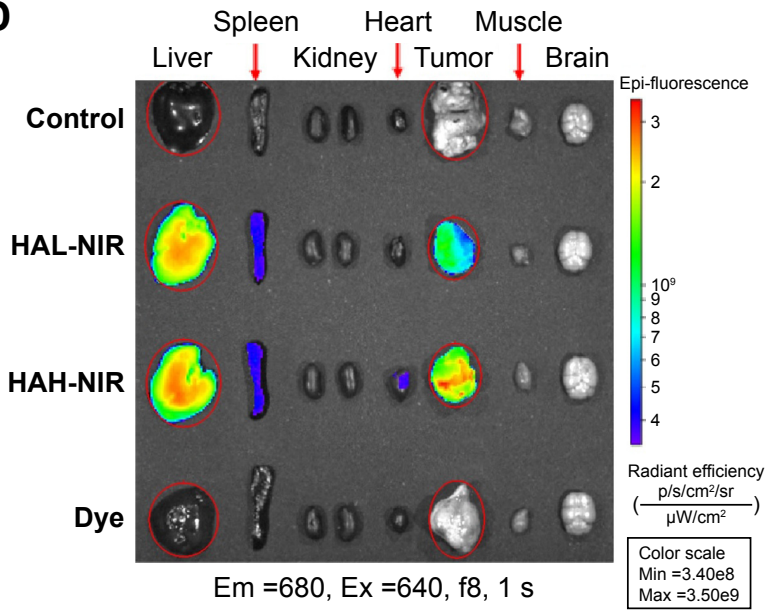

C

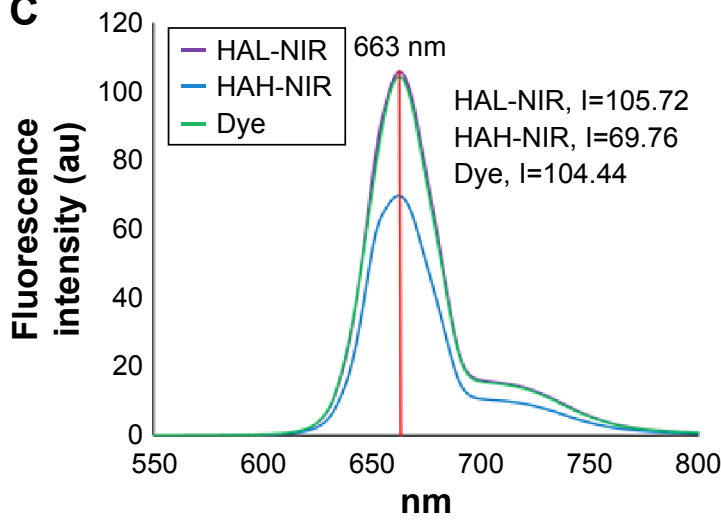

$\mathbf{E}$

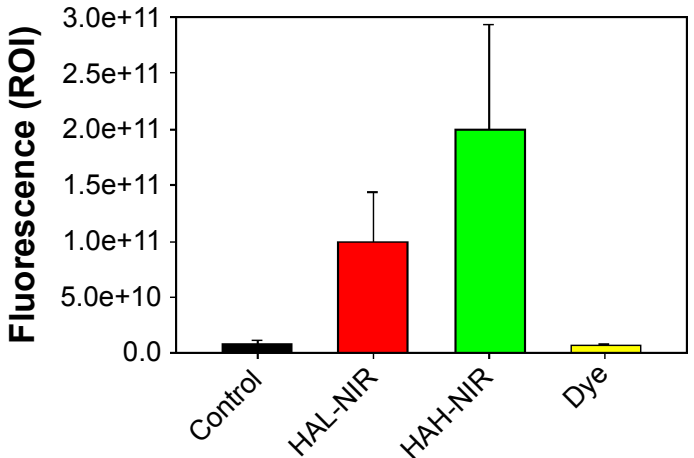

Figure 6 In vivo fluorescence imaging of HA-NIR dye with different molecular weight of HA.

Notes: (A) Time-dependent distribution of HA-NIR was measured by the IVIS Xenogen imaging system after HA-NIR dye administration intravenously (HA-NIR dye: $20 \mathrm{mg} / \mathrm{mL}, 200 \mathrm{mg} / \mathrm{kg}$ ). (B) Quantification of fluorescence signal on the tumor site ( $\mathrm{n}=3$ ). (C) Fluorescence spectra of HAH-NIR, HAL-NIR and dye. (D) The fluorescence images of each organ and (E) fluorescence quantification of the tumor images of mice treated with HAL-NIR, HAH-NIR or free dye at $48 \mathrm{~h}$ postinjection ( $n=3$ ).

Abbreviations: $\mathrm{HA}$, hyaluronic acid; $\mathrm{HAH}, \mathrm{HA}$ with high molecular weight; $\mathrm{HAL}$, $\mathrm{HA}$ with low molecular weight; IVIS, in vivo imaging system; min, minimum, max, maximum; $\mathrm{ROI}$, region of interest.

postinjection. Interestingly, the fluorescence intensity on the tumor area in HAL-NIR group reached a plateau at $8 \mathrm{~h}$ postinjection intravenously. Compared to the results of HALNIR group, HAH-NIR showed a lower tumor accumulation at $1 \mathrm{~h}$ postinjection, which may be due to the $34 \%$ lower fluorescence intensity of HAH-NIR at the initial $20 \mathrm{mg} / \mathrm{mL}$ concentration of HA-NIR (Figure 6C).

Uptake of HAH-NIR or HAL-NIR in different organs was determined in mice at $48 \mathrm{~h}$ postinjection and the results are shown in Figure 6D. Clearly, significantly higher accumulation of both NIR dye-labeled HA was observed in the liver, which is responsible for the elimination of HA from the circulation. ${ }^{59,60}$ Besides, it was found that HA-NIR accumulated in the tumor region, indicating active targeting ability of HA in CD44 receptor overexpressing tumors. ${ }^{61,62}$ HA-NIR was also found to be present in spleen and heart. To further investigate the differences in tumor accumulation between HAH-NIR and HAL-NIR at $48 \mathrm{~h}$ postinjection, the fluorescence intensity of isolated tumor (Figure 6D) was analyzed by Living Image software. As shown in Figure 6E, the quantification of fluorescence signals of isolated tumor revealed two times higher fluorescence intensity of HAHNIR than that of HAL-NIR group, indicating the higher accumulation of HA with high molecular weight in CD44overexpressing HT-29 tumors.

\section{Cell growth inhibition by HA-nimesulide}

Cell viability in the presence of $\mathrm{NiNO}_{2}$ (nimesulide), $\mathrm{NiNH}_{2}$ (modified nimesulide), HA-nimesulide and HA was evaluated by MTT assay in HT-29 and HCT-15 cells. As shown in Figure 7A, the $\mathrm{IC}_{50}$ of free nimesulide was approximately $1,600 \mu \mathrm{M}$ in HT-29 and HCT-15 cells; however, the cell survival rate of $\mathrm{NiNH}_{2}$-treated groups was $>78 \%$ in both HT-29 and HCT-15 cells at 1,600 $\mu \mathrm{M}$. After HA was added to the cells and incubated for $48 \mathrm{~h}$, the cytotoxicity of HA in HT-29 cells and HCT-15 cells slightly increased. As shown 

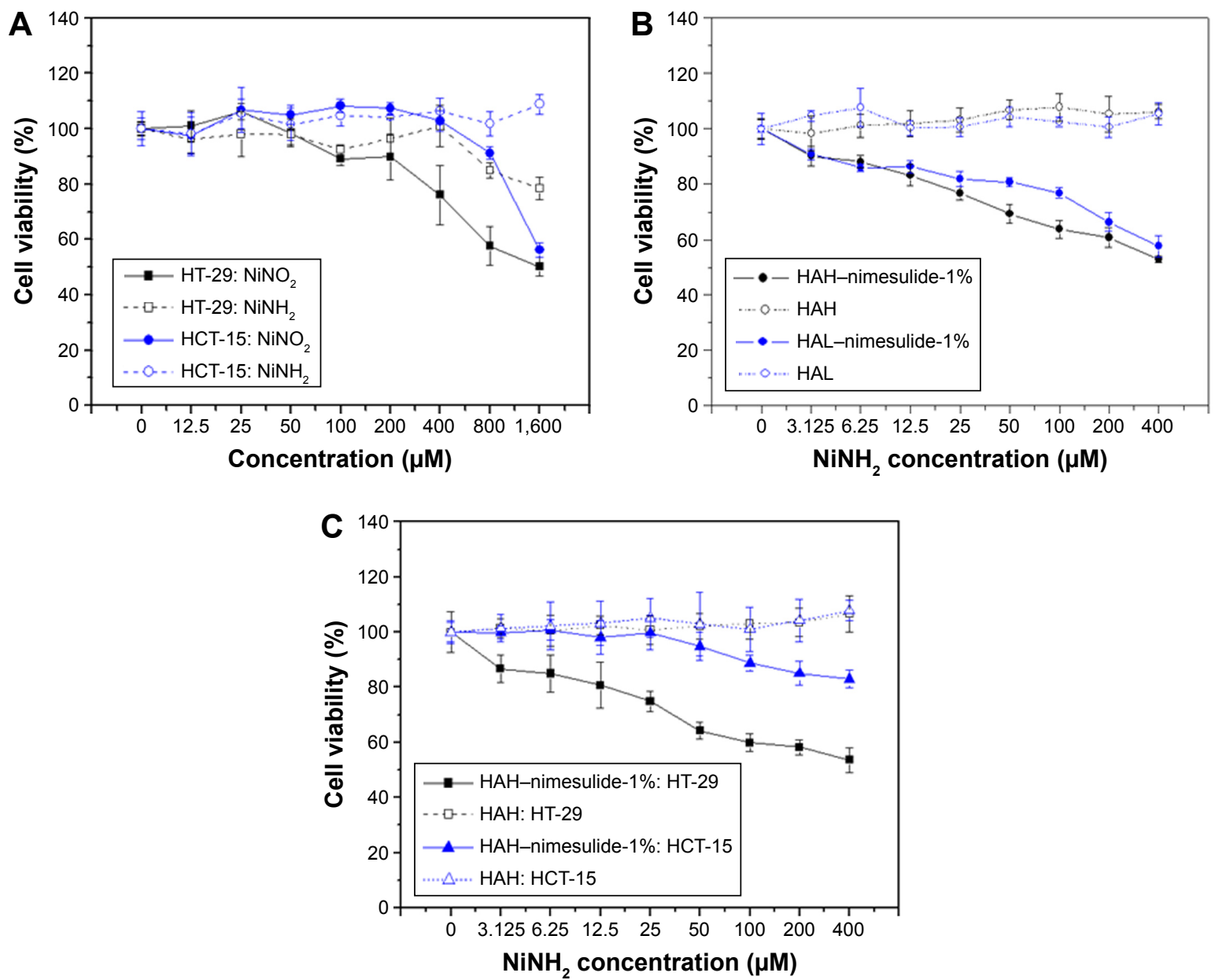

Figure 7 (A) Cell viability assessment of $\mathrm{NiNH}_{2}$ and $\mathrm{NiNO}_{2}$ (nimesulide) in HT-29 and HCT-15 cells. (B) Viability of HT-29 cells in HAL-nimesulide- $1 \%$ or HAHnimesulide- $1 \%$ for $48 \mathrm{~h}$ and (C) cell viability of HT-29 and HCT-15 cells treated with HAH-nimesulide- $1 \%$ for $48 \mathrm{~h}$.

Abbreviations: $\mathrm{NiNH}_{2}, \mathrm{~N}$-(4-amino-2-phenoxyphenyl)methanesulfonamide; HA, hyaluronic acid; HAH, HA with high molecular weight; HAL, HA with low molecular weight.

in Figure 7B, HAL-nimesulide conjugate displayed 42.4\% cell killing ability, whereas $\mathrm{HAH}-$ nimesulide gave a survival rate of $52.9 \%$ at the equivalent nimesulide $(400 \mu \mathrm{M})$ concentration in HT-29 cells. Exiguous cytotoxic effects were observed on HCT-15 cells, indicating that HA-nimesulide causes cell death in high-level CD44 expressing HT-29 cells (Figure 7C).

$\mathrm{NiNH}_{2}$ is one of the major metabolites of nimesulide, ${ }^{63}$ and the nitro group of nimesulide can be fully reduced to an amine group through catalysis by $\mathrm{P} 450$ and/or reductase. ${ }^{64}$ The toxicity of nimesulide to hepatocytes has been previously observed ${ }^{65,66}$ which is attributed mainly to the nitro group in its structure.$^{67}$ After reduction, $\mathrm{NiNH}_{2}$ exhibits reduced toxicity than nimesulide in hepatocytes because nimesulide is a powerful protonophoretic uncoupler and $\mathrm{NAD}(\mathrm{P}) \mathrm{H}$ oxidant. ${ }^{67}$ In addition, $\mathrm{NiNH}_{2}$ can completely suppress the uncoupling and $\mathrm{NAD}(\mathrm{P}) \mathrm{H}$ oxidant effects on mitochondria. ${ }^{68,69}$ In this study, the nitro group of nimesulide was reduced to amine first and then grafted onto HA, suggesting that HA-nimesulide might reduce the liver toxicity effects of free nimesulide.

\section{Apoptotic analysis of HA-nimesulide- treated HT-29 cells}

To further confirm the role of programmed cell death involved in the cytotoxic effect of HAL-nimesulide, apoptotic analysis using Annexin-V/propidium iodide double staining was performed in HAL-nimesulide-treated HT-29 cells. As shown in Figure 8A and B, the sum percentage of cell apoptosis, including late apoptosis (Q2) and early apoptosis (Q3), was 81.1\% (Q2 and Q3: 25.6\% and 55.5\%, respectively) in $\mathrm{H}_{2} \mathrm{O}_{2}$-treated cells (positive control groups), whereas cell apoptosis percentage was $2.9 \%$ in negative control group (Q2 and Q3: 0.3\% and 2.6\%, respectively). Upon treatment with HAL-nimesulide at $200 \mu \mathrm{M}$ nimesulide concentration, the percentage of apoptotic cells increased to 47.1\% (Q2 and Q3: 4.6\% and 42.5\%, respectively) as shown 


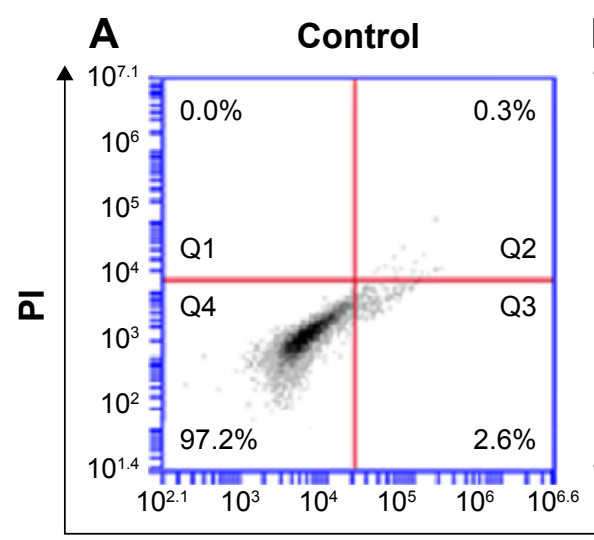

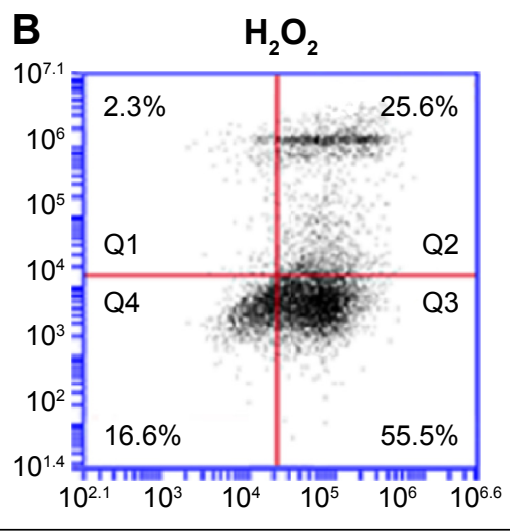

Annexin-V

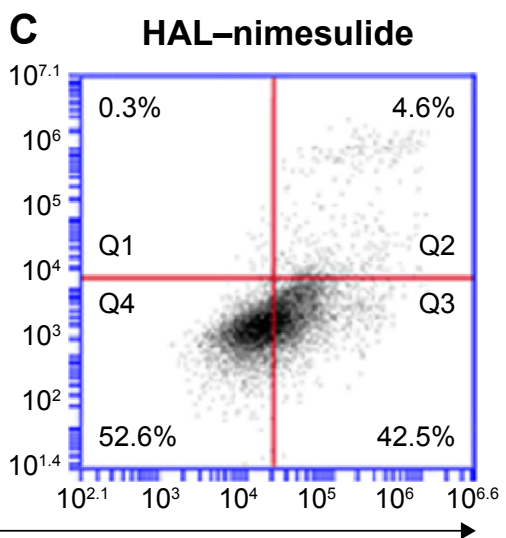

Figure 8 Apoptotic analysis of HT-29 cells using Annexin V-FITC and PI double staining.

Notes: (A) Negative control group; (B) cells treated with $\mathrm{H}_{2} \mathrm{O}_{2}$ at $10 \mathrm{mM}$ as positive control group and (C) cells treated with $\mathrm{HAL}-$ nimesulide at $200 \mu \mathrm{M}$ nimesulide concentration for $48 \mathrm{~h}$. The $\mathrm{X}$-axis represents the density of Annexin V-FITC, whereas the $\mathrm{Y}$-axis represents the density of PI.

Abbreviations: FITC, fluorescein isothiocyanate; PI, propidium iodide; HA, hyaluronic acid; HAL, HA with low molecular weight.

in Figure 8C. Interestingly, significantly high percentage of early apoptosis was observed in $\mathrm{HAL}$-nimesulide-treated cells (Figure 8C, Q3), compared with that of $\mathrm{H}_{2} \mathrm{O}_{2}$-treated cells (Figure 8B, Q3), indicating different mechanisms of cell apoptosis.

In recent years, nimesulide has been shown to inhibit cancer cell growth and exert antitumor effects against hypopharyngeal carcinoma cells, ${ }^{41}$ lung tumors ${ }^{70}$ and gastric adenocarcinoma cells. ${ }^{40}$ Jia-Jun et al demonstrated that nimesulide inhibits the proliferation of hypopharyngeal carcinoma cells by survivin inhibition and caspase-3, Bcl2 and Bax expression. ${ }^{41} \mathrm{Li}$ et al found that nimesulide induces gastric adenocarcinoma cell apoptosis and cell cycle arrest by up-regulation of P27kip1. ${ }^{40}$ In this study, we demonstrated that HA-nimesulide significantly induced early apoptosis in HT-29 colorectal cells as reported previously, leading to cell-killing activity for further cancer treatment. The detailed mechanisms remain unclear, and related evaluations are ongoing at our lab.

\section{HA-nimesulide inhibits the growth of nude mice bearing HT-29 xenografts}

The antitumor effects of HAL-nimesulide and HAHnimesulide conjugates were assessed in HT-29 xenografted tumor model. All tumor-injected mice had similar thigh size on day 0 . The dosage of free nimesulide and nimesulide conjugated to HA used in the study was $1.5 \mathrm{mg} / \mathrm{kg}$ three times weekly; $50 \mathrm{mg} / \mathrm{kg} 5-\mathrm{FU}$ was administered once per week by intravenous injection. Figure 9 depicts decreases in tumor volume with HAL-nimesulide (TGI $\%=82.3 \% \pm 5.0 \%$ ) and $\mathrm{HAH}-$ nimesulide $($ TGI $\%=$ $76.4 \% \pm 6.9 \%$ ) $<5$-FU (TGI $\%=70.7 \% \pm 17.0 \%$ ) $<$ free nimesulide (TGI $\%=55.9 \% \pm 6.9 \%$ ), compared with untreated control animals. The antitumor effects of HA-nimesulide conjugates may be due to the release of glycosylated or oligosaccharide nimesulide from HA-nimesulide conjugates after HA degradation, because we observed on NMR oligosaccharide nimesulide signals after hyaluronidases treatment (data not shown). Studies investigating the mechanisms of HA-nimesulide inhibition of tumor growth and the detailed structures of glycosylated or oligosaccharide nimesulide are ongoing in our laboratory.

Examination of hematoxylin and eosin-stained tissue sections revealed differences in tissue morphology between the treatment groups. As shown in Figure 10, no noticeable morphologic differences were observed in the liver or kidney in each group. Importantly, the tumor region revealed scathe phenomena after the injection of HA-nimesulide, whereas cell mitosis was easily observed in the PBS control group and nimesulide-treated group. To determine whether HA-nimesulide induced cell death through tumor cell apoptosis, the frequency of apoptotic cells in paraffin-embedded HT-29 tumor sections from each group was analyzed in a TUNEL assay. As shown in Figure 11, the colocalization of nuclei (Hoechst staining, shown in red) and TUNEL-positive apoptotic cells (green) in tumor sections was significantly increased in the group with HA-nimesulide, whereas no significant TUNEL fluorescence was observed in the control group. Few green fluorescence positive cells were observed in the nimesulide-treated group. These observations further corroborate the results of our in vitro cytotoxicity studies.

$\mathrm{Du}$ et al demonstrated that $\mathrm{CD}_{4} 4^{+}$cells isolated from $\mathrm{CRC}$ have the capacity for clonal expansion and xenograft initiation, but CD44 knockdown in cells significantly inhibits 
A

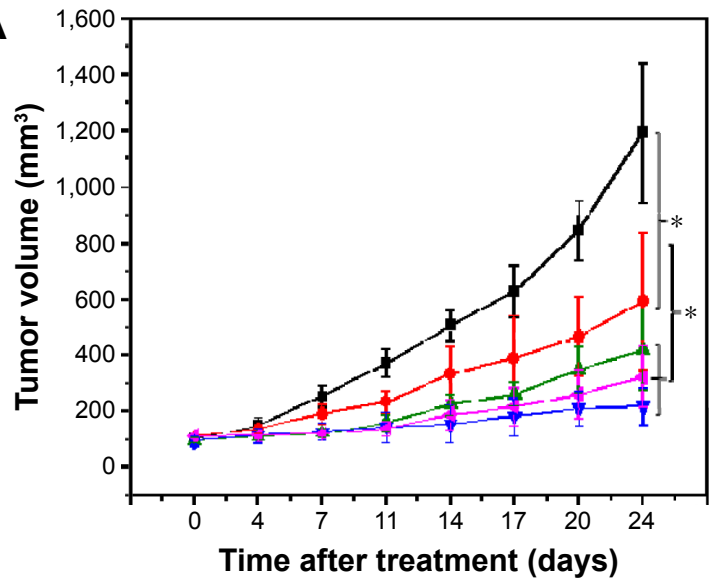

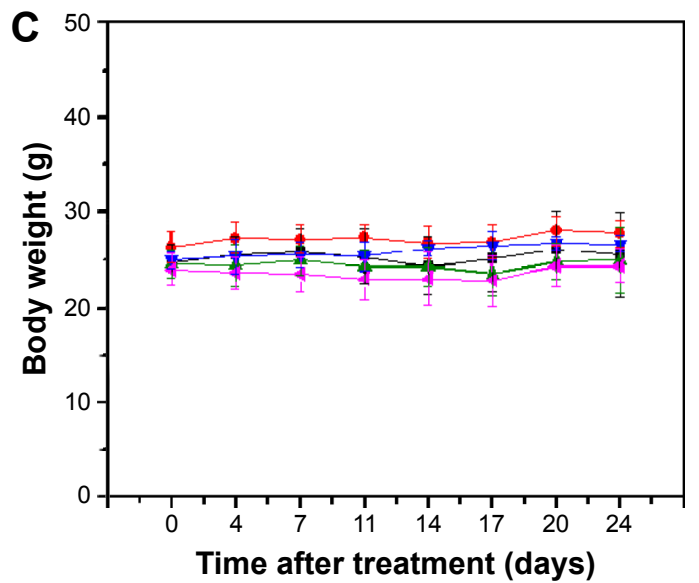

$\rightarrow$ Control $\rightarrow$ Nimesulide $\rightarrow$-Fu $\rightarrow$ HAL-nimesulide $\rightarrow$ HAH-nimesulide

B
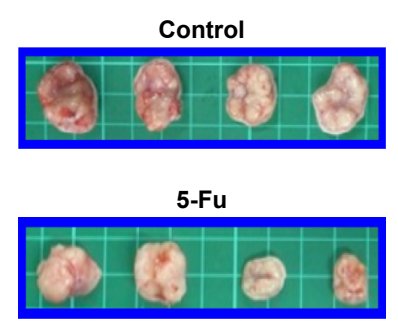
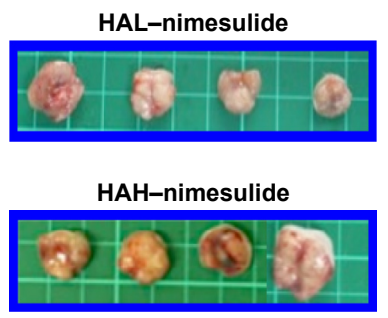

Nimesulide

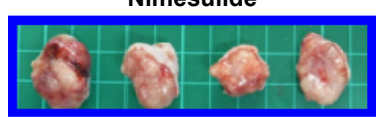

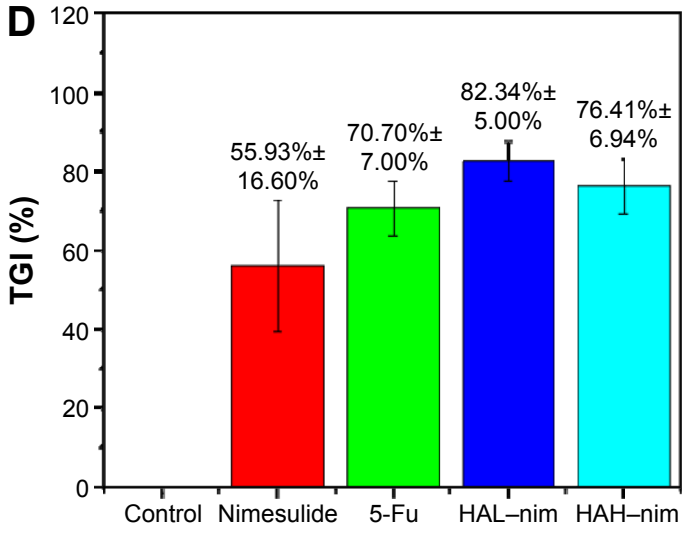

Groups

Figure 9 In vivo antitumor effects of HA-nimesulide in nude mice bearing HT-29 xenografts.

Notes: Nude mice were implanted subcutaneously with HT-29 cells and treated three times weekly with $0.2 \mathrm{~mL}$ PBS, nimesulide (I.5 mg/kg), HA-nimesulide (I.5 mg/kg equivalent nimesulide concentration) or 5 -FU (50 mg/kg) once per week. (A) Tumor size and (B) body weight of mice after treatment with drugs. (C) Organ morphology, tumor weight and (D) TGI \% after treatment with drugs. Statistical significances were determined using the One-way ANOVA followed by Bonferroni tests, $* P<0.05$. Abbreviations: 5-FU, 5-fluorouracil; ANOVA, analysis of variance; HA, hyaluronic acid; HAH, HA with high molecular weight; HAL, HA with low molecular weight; PBS, phosphate-buffered saline; TGI, tumor growth inhibition.

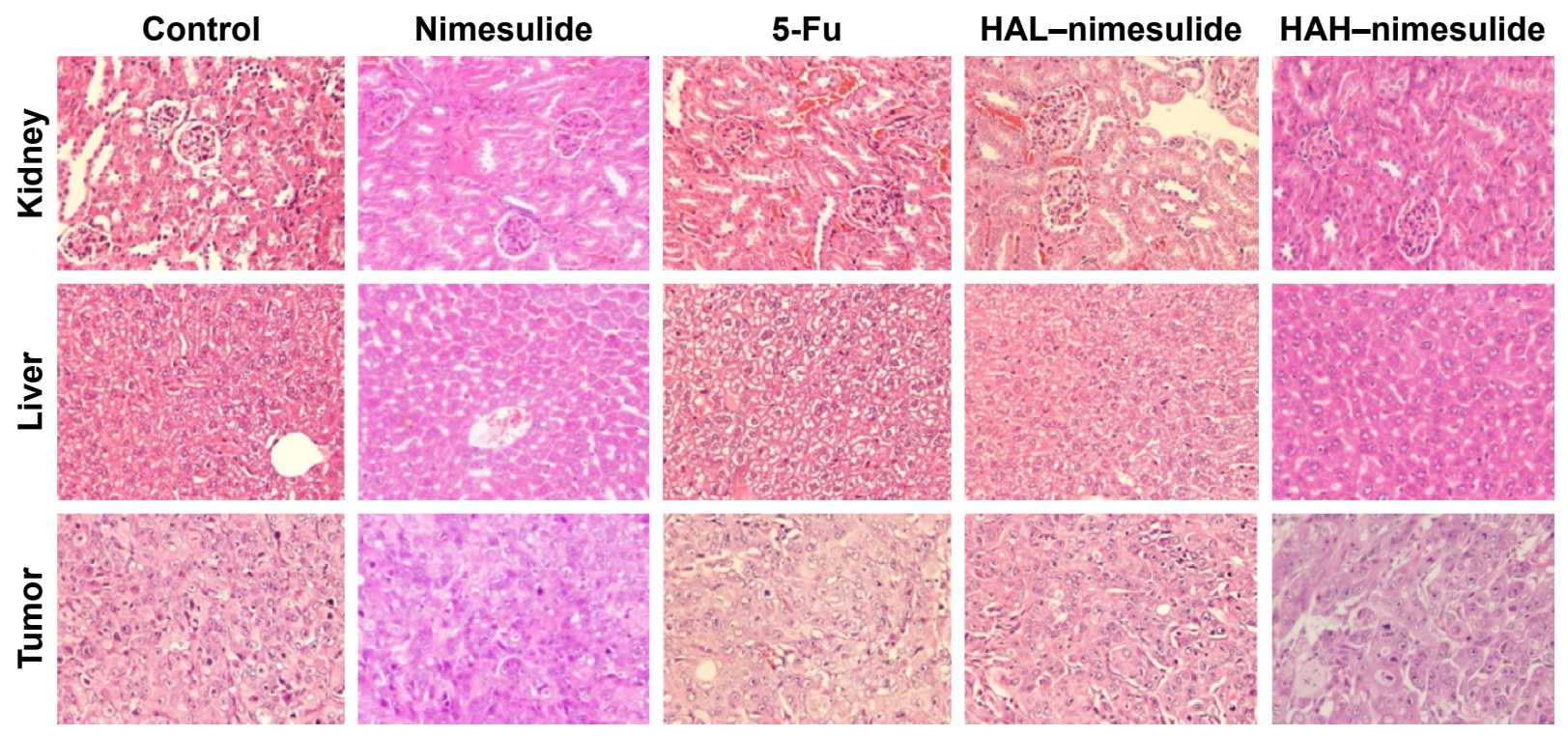

Figure 10 Histologic assessment of liver, kidney and tumor after treatment with PBS, 5-FU, nimesulide or HA-nimesulide in nude mice bearing HT-29 xenografts (400x). Abbreviations: 5-FU, 5-fluorouracil; HA, hyaluronic acid; PBS, phosphate-buffered saline. 

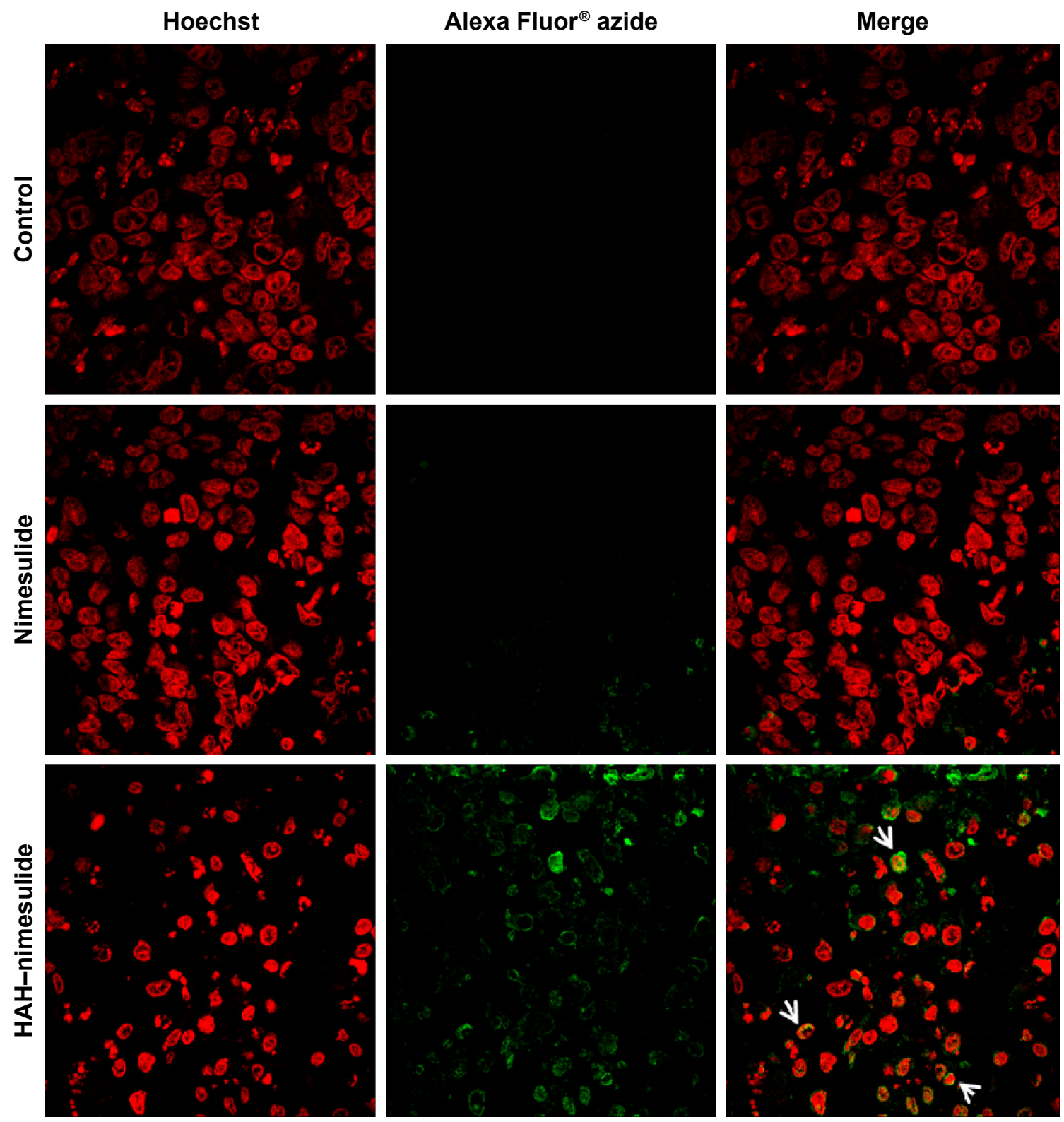

Figure I I Detection of DNA strand breaks by TUNEL assay in nude mice bearing HT-29 xenografts treated with PBS, nimesulide or HAH-nimesulide.

Abbreviations: HA, hyaluronic acid; HAH, HA with high molecular weight; PBS, phosphate-buffered saline; TUNEL, terminal deoxynucleotidyl transferase dUTP nick end-labeling.

tumor initiation and development in nude mice. ${ }^{71}$ Clinical research has indicated that $\mathrm{CD} 44^{+} \mathrm{CRC}$ patients retain a high risk of recurrence. ${ }^{72}$ Hence, CD44 expression in CRC has been found to have a vital role in both in vivo and clinical studies. It is reported that patients with long-standing inflammatory bowel disease have an increased risk of developing CRC. The as-prepared HA-nimesulide conjugates may have the potential to act as antitumor/inflammatory agents to treat $\mathrm{CD} 44^{+} \mathrm{CRC}$ tumor and inflammatory bowel disease. Recently, it was demonstrated that HA-based nanoparticles or liposomal capping HA-based nanoparticles significantly prolonged the blood circulation time, enhanced accumulation in $\mathrm{CD} 44^{+}$tumor area and improved therapeutic efficacy of doxorubicin in vivo. ${ }^{73}$ In this study, the as-synthesized HAnimesulide conjugate was in hydrogel form that could be injected into mice intravenously, and it successfully inhibited the growth of CD44-expressing HT-29 tumor in vivo. It is believed that HA-nimesulide conjugate hydrogel has a great potential to be administrated topically for other biomedical applications.

Recently, improvement in water solubility or circulation time of potential drugs has attracted the attention of researchers. Pegylation is useful approach to achieve this goal in clinical drug delivery systems such as pegylated interferon 
$\alpha-2 b$ or pegylated liposomes. ${ }^{74,75}$ Halyation of drugs can be a new class of drug-polymer platforms for CD44-targetable delivery system. In antitumor studies, HA-nimesulide can inhibit HT-29 tumor growth, but cannot completely eradicate the whole tumors. Further combination treatments of HA-nimesulide with current chemotherapeutic drugs such as 5-FU or irinotecan might be necessary for cancer therapy. After combination with HA-nimesulide, the dosage of chemotherapeutic drugs for effective antitumor treatments can be reduced, thereby decreasing the side effects of chemotherapy. Related studies are ongoing in our lab.

\section{Conclusion}

In our research, we successfully overcame the limitation of hydrophilicity of nimesulide using drug-HA conjugated delivery system by carbodiimide coupling and the structure of HA-nimesulide was characterized by ${ }^{1} \mathrm{H}$ NMR $400 \mathrm{MHz}$ and TOCSY. HA-nimesulide conjugate showed high selectivity to CD44-overexpressing HT-29 tumors in inducing potent cell toxicity in vitro. Regarding in vivo studies, dye-labeled HA displayed tumor accumulation as observed by IVIS, and HA-nimesulide exhibited remarkable antitumor activity by apoptotic mechanisms without noticeable morphologic differences in the liver or kidney in HT-29 xenografted mice. Thus, HA-nimesulide delivery systems have a great potential as a new class of bioconjugated and tumor-targeted chemotherapeutic drugs for cancer treatment.

\section{Acknowledgment}

This work was supported by the Ministry of Science and Technology (103-2113-M-005-008-MY3). We also thank Holy Stone Healthcare Co., Ltd. for providing HA.

\section{Disclosure}

The authors report no conflicts of interest in this work.

\section{References}

1. Chang YT, Tseng HC, Huang CC, et al. Relative down-regulation of apoptosis and autophagy genes in colorectal cancer. Eur J Clin Invest. 2011; 41(1):84-92.

2. André T, Boni C, Mounedji-Boudiaf L, et al. Oxaliplatin, fluorouracil, and leucovorin as adjuvant treatment for colon cancer. $N$ Engl J Med. 2004;350(23):2343-2351.

3. Douillard JY, Cunningham D, Roth AD, et al. Irinotecan combined with fluorouracil compared with fluorouracil alone as first-line treatment for metastatic colorectal cancer: a multicentre randomised trial. Lancet. 2000; 355(9209): 1041-1047.

4. Li J, Hou N, Faried A, Tsutsumi S, Kuwano H. Inhibition of autophagy augments 5-fluorouracil chemotherapy in human colon cancer in vitro and in vivo model. Eur J Cancer. 2010;46(10):1900-1909.

5. Longley DB, Allen WL, Johnston PG. Drug resistance, predictive markers and pharmacogenomics in colorectal cancer. Biochim Biophys Acta. 2006;1766(2):184-196.
6. Herrera-Gayol A, Jothy S. Adhesion proteins in the biology of breast cancer: contribution of CD44. Exp Mol Pathol. 1999;66(2):149-156.

7. Goodison S, Urquidi V, Tarin D. CD44 cell adhesion molecules. Mol Pathol. 1999;52(4):189-196.

8. Alves CS, Yakovlev S, Medved L, Konstantopoulos K. Biomolecular characterization of CD44-fibrin(ogen) binding: distinct molecular requirements mediate binding of standard and variant isoforms of CD44 to immobilized fibrin(ogen). J Biol Chem. 2009;284(2):1177-1189.

9. Cheng C, Sharp PA. Regulation of CD44 alternative splicing by SRm160 and its potential role in tumor cell invasion. Mol Cell Biol. 2006;26(1): 362-370.

10. Aruffo A, Stamenkovic I, Melnick M, Underhill CB, Seed B. CD44 is the principal cell-surface receptor for hyaluronate. Cell. 1990;61(7): 1303-1313.

11. Ponta H, Sherman L, Herrlich PA. CD44: from adhesion molecules to signalling regulators. Nat Rev Mol Cell Biol. 2003;4(1):33-45.

12. Dalerba P, Dylla SJ, Park IK, et al. Phenotypic characterization of human colorectal cancer stem cells. Proc Natl Acad Sci U S A. 2007; 104(24):10158-10163.

13. Merlos-Suarez A, Barriga FM, Jung P, et al. The intestinal stem cell signature identifies colorectal cancer stem cells and predicts disease relapse. Cell Stem Cell. 2011;8(5):511-524.

14. Wang C, Xie J, Guo J, Manning HC, Gore JC, Guo N. Evaluation of CD44 and CD133 as cancer stem cell markers for colorectal cancer. Oncol Rep. 2012;28(4):1301-1308.

15. Misra S, Heldin P, Hascall VC, et al. Hyaluronan-CD44 interactions as potential targets for cancer therapy. FEBS J. 2011;278(9): $1429-1443$.

16. Liu K, Wang ZQ, Wang SJ, et al. Hyaluronic acid-tagged silica nanoparticles in colon cancer therapy: therapeutic efficacy evaluation. Int $J$ Nanomedicine. 2015;10:6445-6454.

17. Turley EA, Noble PW, Bourguignon LY. Signaling properties of hyaluronan receptors. J Biol Chem. 2002;277(7):4589-4592.

18. Segura T, Anderson BC, Chung PH, Webber RE, Shull KR, Shea LD. Crosslinked hyaluronic acid hydrogels: a strategy to functionalize and pattern. Biomaterials. 2005;26(4):359-371.

19. Underhill C. CD44: the hyaluronan receptor. J Cell Sci. 1992;103(Pt 2): 293-298.

20. Kawada $\mathrm{C}$, Yoshida $\mathrm{T}$, Yoshida $\mathrm{H}$, et al. Ingested hyaluronan moisturizes dry skin. Nutr J. 2014;13:70.

21. Kota DJ, Prabhakara KS, Cox CS, Olson SD. MSCs and hyaluronan: sticking together for new therapeutic potential? Int J Biochem Cell Biol. 2014;55:1-10.

22. Allison DD, Grande-Allen KJ. Review. Hyaluronan: a powerful tissue engineering tool. Tissue Eng. 2006;12(8):2131-2140.

23. Song S, Qi H, Xu J, et al. Hyaluronan-based nanocarriers with CD44-overexpressed cancer cell targeting. Pharm Res. 2014;31(11): 2988-3005.

24. Xu K, Lee F, Gao SJ, Chung JE, Yano H, Kurisawa M. Injectable hyaluronic acid-tyramine hydrogels incorporating interferon-alpha2a for liver cancer therapy. J Control Release. 2013;166(3):203-210.

25. Yoon HY, Kim HR, Saravanakumar G, et al. Bioreducible hyaluronic acid conjugates as siRNA carrier for tumor targeting. J Control Release. 2013;172(3):653-661.

26. Manju S, Sreenivasan K. Conjugation of curcumin onto hyaluronic acid enhances its aqueous solubility and stability. J Colloid Interface Sci. 2011;359(1):318-325.

27. Saravanakumar G, Deepagan VG, Jayakumar R, Park JH. Hyaluronic acid-based conjugates for tumor-targeted drug delivery and imaging. J Biomed Nanotechnol. 2014;10(1):17-31.

28. Lee H, Lee K, Park TG. Hyaluronic acid-paclitaxel conjugate micelles: synthesis, characterization, and antitumor activity. Bioconjug Chem. 2008;19(6):1319-1325.

29. Stern R, Asari AA, Sugahara KN. Hyaluronan fragments: an information-rich system. Eur J Cell Biol. 2006;85(8):699-715.

30. Cowman MK, Matsuoka S. Experimental approaches to hyaluronan structure. Carbohydr Res. 2005;340(5):791-809. 
31. West DC, Hampson IN, Arnold F, Kumar S. Angiogenesis induced by degradation products of hyaluronic acid. Science. 1985;228(4705): 1324-1326.

32. Rothman I, Stanford JL, Kuniyuki A, Berger RE. Self-report of prostatitis and its risk factors in a random sample of middle-aged men. Urology. 2004;64(5):876-879; discussion 879-880.

33. Loftus EV Jr. Epidemiology and risk factors for colorectal dysplasia and cancer in ulcerative colitis. Gastroenterol Clin North Am. 2006; 35(3):517-531.

34. Davis R, Brogden RN. Nimesulide. An update of its pharmacodynamic and pharmacokinetic properties, and therapeutic efficacy. Drugs. 1994;48(3):431-454.

35. Gianiorio P, Zappa R, Sacco O, Fregonese B, Scaricabarozzi I, Rossi GA. Antipyretic and anti-inflammatory efficacy of nimesulide vs paracetamol in the symptomatic treatment of acute respiratory infections in children. Drugs. 1993;46(Suppl 1):204-207.

36. Okajima E, Denda A, Ozono S, et al. Chemopreventive effects of nimesulide, a selective cyclooxygenase-2 inhibitor, on the development of rat urinary bladder carcinomas initiated by N-butyl-N-(4-hydroxybutyl) nitrosamine. Cancer Res. 1998;58(14):3028-3031.

37. Fukutake M, Nakatsugi S, Isoi T, et al. Suppressive effects of nimesulide, a selective inhibitor of cyclooxygenase-2, on azoxymethaneinduced colon carcinogenesis in mice. Carcinogenesis. 1998;19(11): 1939-1942.

38. Nakatsugi S, Ohta T, Kawamori T, et al. Chemoprevention by nimesulide, a selective cyclooxygenase-2 inhibitor, of 2-amino-1-methyl6-phenylimidazo[4,5-b]pyridine ( $\mathrm{PhIP}$ )-induced mammary gland carcinogenesis in rats. Cancer Sci. 2000;91(9):886-892.

39. Furukawa F, Nishikawa A, Lee IS, et al. A cyclooxygenase- 2 inhibitor, nimesulide, inhibits postinitiation phase of $\mathrm{N}$-nitrosobis(2-oxopropyl) amine-induced pancreatic carcinogenesis in hamsters. Int $J$ Cancer. 2003;104(3):269-273.

40. Li JY, Wang XZ, Chen FL, Yu JP, Luo HS. Nimesulide inhibits proliferation via induction of apoptosis and cell cycle arrest in human gastric adenocarcinoma cell line. World J Gastroenterol. 2003;9(5):915-920.

41. Jia-Jun T, Su-Mei L, Liang Y, et al. Nimesulide inhibited the growth of hypopharyngeal carcinoma cells via suppressing survivin expression. Head Neck Oncol. 2012;4:7.

42. Zhong B, Cai X, Chennamaneni S, et al. From COX-2 inhibitor nimesulide to potent anti-cancer agent: synthesis, in vitro, in vivo and pharmacokinetic evaluation. Eur J Med Chem. 2012;47(1):432-444.

43. Li XH, Li JJ, Zhang HW, et al. Nimesulide inhibits tumor growth in mice implanted hepatoma: overexpression of Bax over Bcl-2. Acta Pharmacol Sin. 2003;24(10):1045-1050.

44. Fallavena PRB, Schapoval EES. pKa determination of nimesulide in methanol-water mixtures by potentiometric titrations. Int $J$ Pharm. 1997;158(1):109-112.

45. Neha A, Singh I, Sharma M, Tarun G. An approach for improvement of the water solubility of nimesulide in solid dispersion with PEG. IOSR $J$ Pharm. 2012;2(2):153-154.

46. Macpherson D, Best SA, Gedik L, Hewson AT, Rainsford K, Parisi S. The biotransformation and pharmacokinetics of 14C-nimesulide in humans following a single dose oral administration. J Drug Metab Toxicol. 2013;4:140.

47. Luo L, Tao W, Bourkaib N, Luo Y. Design and content determination of nimesulide injectable formulation. Pak J Pharm Sci. 2015; 28(4):1195-1201.

48. Cignarella G, Vianello P, Berti F, Rossoni G. Synthesis and pharmacological evaluation of derivatives structurally related to nimesulide. Eur J Med Chem. 1996;31(5):359-364.

49. Pericherla S, Mareddy J, Rani DPR, Gollapudi PV, Pal S. Chemical modifications of nimesulide. J Brazil Chem Soc. 2007;18(2):384-390.

50. Luo Y, Ziebell MR, Prestwich GD. A hyaluronic acid-taxol antitumor bioconjugate targeted to cancer cells. Biomacromolecules. 2000;1(2): 208-218.

51. Lim EK, Kim HO, Jang E, et al. Hyaluronan-modified magnetic nanoclusters for detection of CD44-overexpressing breast cancer by MR imaging. Biomaterials. 2011;32(31):7941-7950.
52. Luo Y, Prestwich GD. Synthesis and selective cytotoxicity of a hyaluronic acid-antitumor bioconjugate. Bioconjug Chem. 1999;10(5): 755-763.

53. Pouyani T, Prestwich GD. Functionalized derivatives of hyaluronic acid oligosaccharides: drug carriers and novel biomaterials. Bioconjug Chem. 1994;5(4):339-347.

54. National Research Council (U.S). Committee for the Update of the Guide for the Care and Use of Laboratory Animals, Institute for Laboratory Animal Research (U.S), National Academies Press (U.S.). Guide for the Care and use of Laboratory Animals. Washington, D.C: National Academies Press; 2011.

55. Nakajima TE, Yasunaga M, Kano Y, et al. Synergistic antitumor activity of the novel SN-38-incorporating polymeric micelles, NK012, combined with 5-fluorouracil in a mouse model of colorectal cancer, as compared with that of irinotecan plus 5-fluorouracil. Int J Cancer. 2008; 122(9):2148-2153.

56. Sharma R, Adam E, Schumacher U. The action of 5-fluorouracil on human HT29 colon cancer cells grown in SCID mice: mitosis, apoptosis and cell differentiation. Br J Cancer. 1997;76(8):1011-1016.

57. Leonelli F, La Bella A, Francescangeli A, et al. A new and simply available class of hydrosoluble bioconjugates by coupling paclitaxel to hyaluronic acid through a 4-hydroxybutanoic acid derived linker. Helv Chim Acta. 2005;88(1):154-159.

58. Cai S, Alhowyan AAB, Yang Q, Forrest WCM, Shnayder Y, Forrest ML. Cellular uptake and internalization of hyaluronan-based doxorubicin and cisplatin conjugates. J Drug Target. 2014;22(7):648-657.

59. Wang W, Cameron AG, Ke S. Developing fluorescent hyaluronan analogs for hyaluronan studies. Molecules. 2012;17(2):1520-1534

60. Zhao MD, Cheng JL, Yan JJ, et al. Hyaluronic acid reagent functional chitosan-PEI conjugate with AQP2-siRNA suppressed endometriotic lesion formation. Int J Nanomedicine. 2016;11:1323-1336.

61. El-Dakdouki MH, Xia J, Zhu DC, et al. Assessing the in vivo efficacy of doxorubicin loaded hyaluronan nanoparticles. ACS Appl Mater Interfaces. 2014;6(1):697-705.

62. Shi J, Ma R, Wang L, et al. The application of hyaluronic acid-derivatized carbon nanotubes in hematoporphyrin monomethyl ether-based photodynamic therapy for in vivo and in vitro cancer treatment. Int $J$ Nanomedicine. 2013;8:2361-2373.

63. Carini M, Aldini G, Stefani R, Marinello C, Facino RM. Mass spectrometric characterization and HPLC determination of the main urinary metabolites of nimesulide in man. J Pharm Biomed Anal. 1998;18(1-2): 201-211.

64. Mizuno K, Katoh M, Okumura H, et al. Metabolic activation of benzodiazepines by CYP3A4. Drug Metab Dispos. 2009;37(2): 345-351.

65. Demiryilmaz I, Turan MI, Kisaoglu A, Gulapoglu M, Yilmaz I, Suleyman H. Protective effect of nimesulide against hepatic ischemia/ reperfusion injury in rats: effects on oxidant/antioxidants, DNA mutation and COX-1/COX-2 levels. Pharmacol Rep. 2014;66(4):647-652.

66. Licata A, Calvaruso V, Cappello M, Craxi A, Almasio PL. Clinical course and outcomes of drug-induced liver injury: nimesulide as the first implicated medication. Dig Liver Dis. 2010;42(2):143-148.

67. Mingatto FE, Rodrigues T, Pigoso AA, Uyemura SA, Curti C, Santos AC. The critical role of mitochondrial energetic impairment in the toxicity of nimesulide to hepatocytes. J Pharmacol Exp Ther. 2002; 303(2):601-607.

68. Mingatto FE, dos Santos AC, Rodrigues T, Pigoso AA, Uyemura SA, Curti C. Effects of nimesulide and its reduced metabolite on mitochondria. Br J Pharmacol. 2000;131(6):1154-1160.

69. Li F, Chordia MD, Huang T, Macdonald TL. In vitro nimesulide studies toward understanding idiosyncratic hepatotoxicity: diiminoquinone formation and conjugation. Chem Res Toxicol. 2009;22(1):72-80.

70. Shaik MS, Chatterjee A, Singh M. Effect of a selective cyclooxygenase-2 inhibitor, nimesulide, on the growth of lung tumors and their expression of cyclooxygenase- 2 and peroxisome proliferator-activated receptorgamma. Clin Cancer Res. 2004;10(4):1521-1529.

71. Du L, Wang H, He L, et al. CD44 is of functional importance for colorectal cancer stem cells. Clin Cancer Res. 2008;14(21):6751-6760. 
72. Wielenga VJ, Heider KH, Offerhaus GJ, et al. Expression of CD44 variant proteins in human colorectal-cancer is related to tumor progression. Cancer Res. 1993;53(20):4754-4756.

73. Li W, Yi X, Liu X, Zhang Z, Fu Y, Gong T. Hyaluronic acid ionpairing nanoparticles for targeted tumor therapy. $J$ Control Release. 2016;225:170-182.

74. Bielack SS, Smeland S, Whelan JS, et al. Methotrexate, doxorubicin, and cisplatin (MAP) plus maintenance pegylated interferon alfa- $2 \mathrm{~b}$ versus MAP alone in patients with resectable high-grade osteosarcoma and good histologic response to preoperative MAP: first results of the EURAMOS-1 good response randomized controlled trial. J Clin Oncol. 2015;33(20):2279-2287.
75. Poveda AM, Selle F, Hilpert F, et al. Bevacizumab combined with weekly paclitaxel, pegylated liposomal doxorubicin, or topotecan in platinum-resistant recurrent ovarian cancer: analysis by chemotherapy cohort of the randomized phase III AURELIA trial. J Clin Oncol. 2015;33(32):3836-3838. 


\section{Supplementary materials}

The GPC spectrum (Figure S1A) results show that the retention time of hyaluronic acid (HA)-nimesulide is similar to original HA. This indicates that the molecular weight would not change obviously. The GPC spectrum (Figure S1B) shows that nimesulide was conjugated to HA by amide bond formation.

The results showed that after $3 \mathrm{~h}$ of incubation, the fluorescein isothiocyanate (FITC) ${ }^{+}$cells in HT-29 and HCT-15 were $66.8 \%$ and $36.3 \%$ (Figure S2), respectively. At 6 and
$24 \mathrm{~h}$ of incubation, the expression of $\mathrm{FITC}^{+}$cells increased (Figure S2). However, the mean fluorescence intensity in HAH-adipic acid dihydrazide (ADH)-FITC-treated HT-29 groups was stronger than in HCT-15 groups. It means the HAH-ADH-FITC uptake amount in HT-29 cells was higher than in HCT-15 cells. These results suggest that the HAH-ADH-FITC uptake by cells was not only regulated by the ligand-receptor pathway, but also mediated by endocytosis.
A

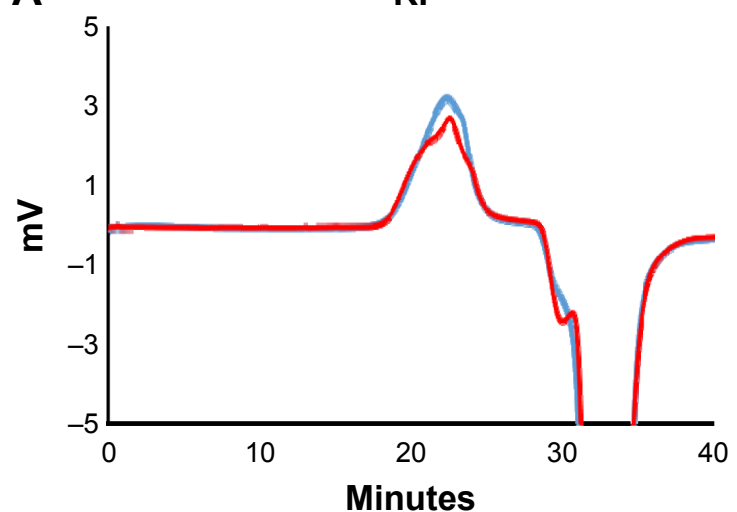

B

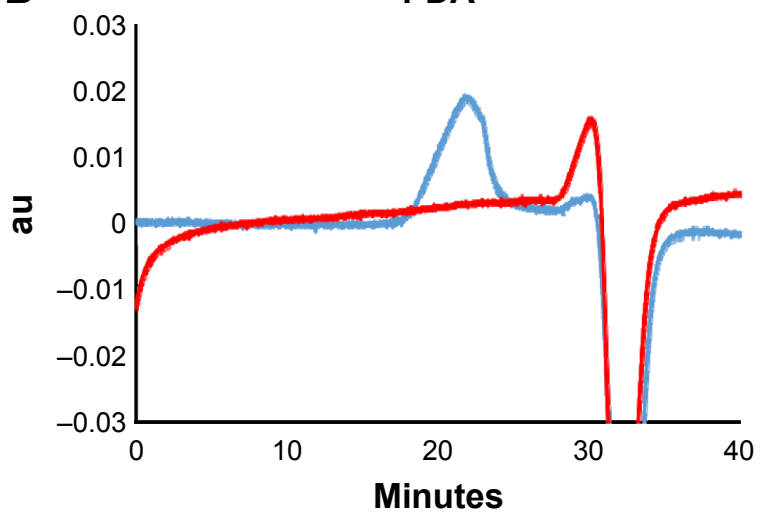

- $\mathrm{HAH}-$ nimesulide-1\% - Free $\mathrm{HAH}$

Figure SI GPC spectrum of HAH-nimesulide and $\mathrm{HAH}$, samples evaluated by $(\mathbf{A})$ refractive index detector and $(\mathbf{B})$ photo diode array. Abbreviations: PDA, phtodiode array; RI, refractive index.
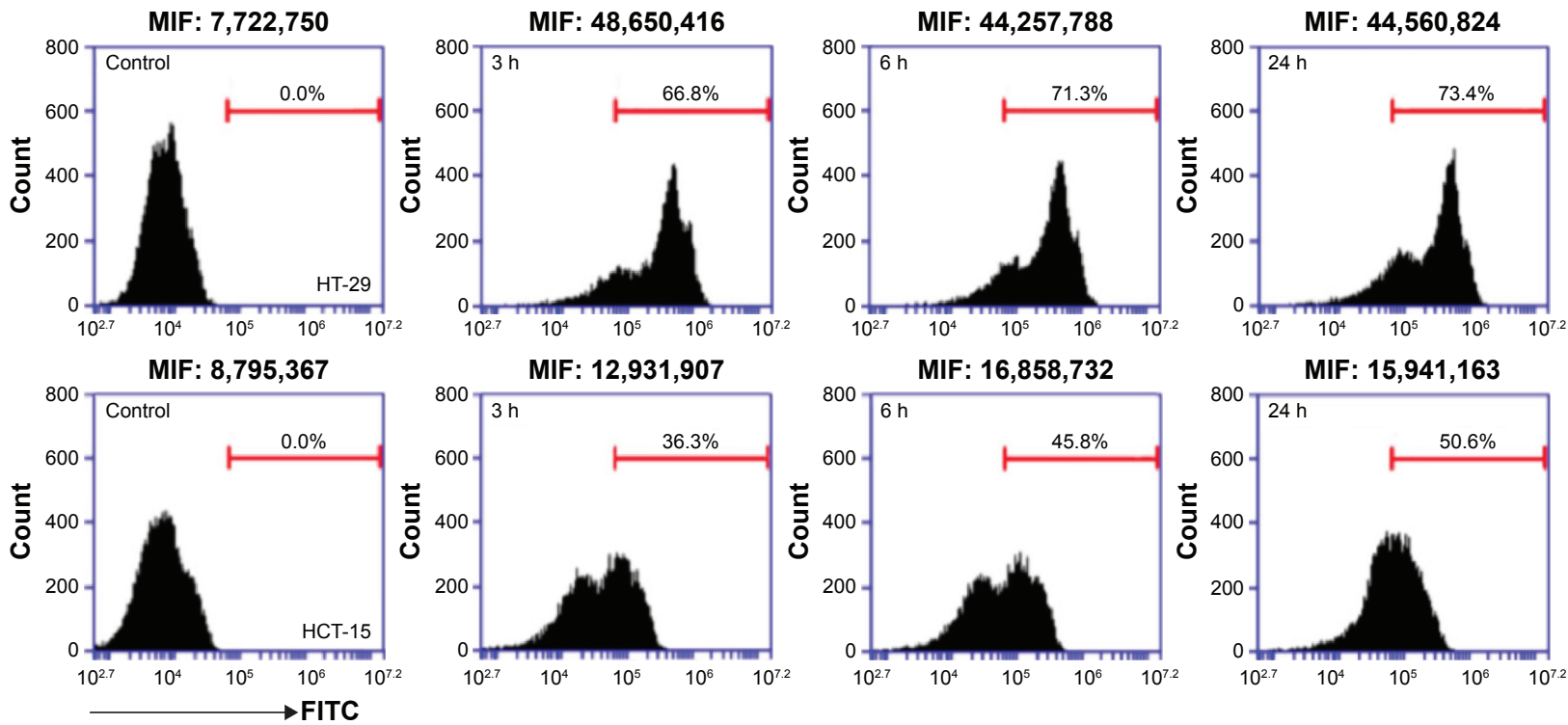

Figure S2 Cellular uptake of HAH-ADH-FITC in HT-29 and HCTI 5 cells.

Abbreviations: ADH, adipic acid dihydrazide; FITC, fluorescein isothiocyanate; MIF, mean fluorescence intensity. 
International Journal of Nanomedicine

Dovepress

\section{Publish your work in this journal}

The International Journal of Nanomedicine is an international, peerreviewed journal focusing on the application of nanotechnology in diagnostics, therapeutics, and drug delivery systems throughout the biomedical field. This journal is indexed on PubMed Central, MedLine, CAS, SciSearch ${ }^{\circledR}$, Current Contents ${ }^{\circledR} /$ Clinical Medicine,
Journal Citation Reports/Science Edition, EMBase, Scopus and the Elsevier Bibliographic databases. The manuscript management system is completely online and includes a very quick and fair peer-review system, which is all easy to use. Visit http://www.dovepress.com/ testimonials.php to read real quotes from published authors.

Submit your manuscript here: http://www.dovepress.com/international-journal-of-nanomedicine-journal 